\title{
THE 2015 PLAINS ELEVATED CONVECTION AT NIGHT FIELD PROJECT
}

\author{
Bart Geerts, David Parsons, Conrad L. Ziegler, Tammy M. Weckwerth, \\ Michael I. Biggerstaff, Richard D. Clark, Michael C. Coniglio, Belay B. Demoz, \\ Richard A. Ferrare, William A. Gallus Jr., Kevin Haghi, John M. Hanesiak, Petra M. Klein, \\ Kevin R. Knupp, Karen Kosiba, Greg M. McFarquhar, James A. Moore, Amin R. Nehrir, \\ Matthew D. Parker, James O. Pinto, Robert M. Rauber, Russ S. Schumacher, David D. Turner, \\ Qing Wang, Xuguang Wang, Zhien Wang, and Joshua Wurman
}

The PECAN field campaign assembled a rich array of observations from lower-tropospheric profiling systems, mobile radars and mesonets, and aircraft over the Great Plains during June-July 2015 to better understand nocturnal mesoscale convective systems and their relationship with the stable boundary layer, the low-level jet, and atmospheric bores.

arge parts of the central Great Plains witness a nocturnal maximum in the frequency of thunder storms and convective precipitation in summer (Kincer 1916; Wallace 1975; Maddox 1980; Heideman and Fritsch 1988; Colman 1990). Much of the rainfall is associated with nocturnal MCSs (please refer to the appendix for a list of all acronyms and their expansions) in a broad swath stretching from the high plains eastward to the Midwest. For example, Fig. 1a shows the 6-yr climatological frequency of organized nocturnal convection ${ }^{1}$ occurring during the warm season (June-August). The PECAN field phase was no

\footnotetext{
${ }^{1}$ Defined in Fig. 1 as a contiguous area of high vertically integrated liquid (corresponding to a column-maximum reflectivity greater than $\sim 35 \mathrm{dBZ}$ ), an area whose maximum width exceeds $100 \mathrm{~km}$ for at least $1 \mathrm{~h}$; see Pinto et al. (2015) for details. Nocturnal is defined here to be between 2100 and 0600 local solar time, which is about $0200-1100$ UTC in the central time zone.
}

exception. In fact, MCSs were more common than normal in the north-central Great Plains during PECAN (Fig. 1b). Many intensive operation periods (IOPs) were conducted near the MCS hot spot in southeastern Nebraska, where more than twice as many MCSs occurred during PECAN than on average over the past 6 years. An MCS climatology developed by NSSL reveals that the preferred region of initiation for large (>150-km length), long-lived ( $>5 \mathrm{~h}$ ) nocturnal MCSs in July (Fig. 2) occurs a few $100 \mathrm{~km}$ to the west of where such MCSs tend to mature (not shown, but roughly the same region as the climatological MCS frequency maximum shown in Fig. 1a). This suggests that these nocturnal systems propagate eastward. Composite radar data analyses by Carbone et al. (2002) and subsequent papers reveal remarkably repetitive envelopes of propagation of deep convection starting near the Front Range of the Rocky Mountains in the afternoon and extending to the lower Great Plains late at night, sometimes continuing farther east the next day. 


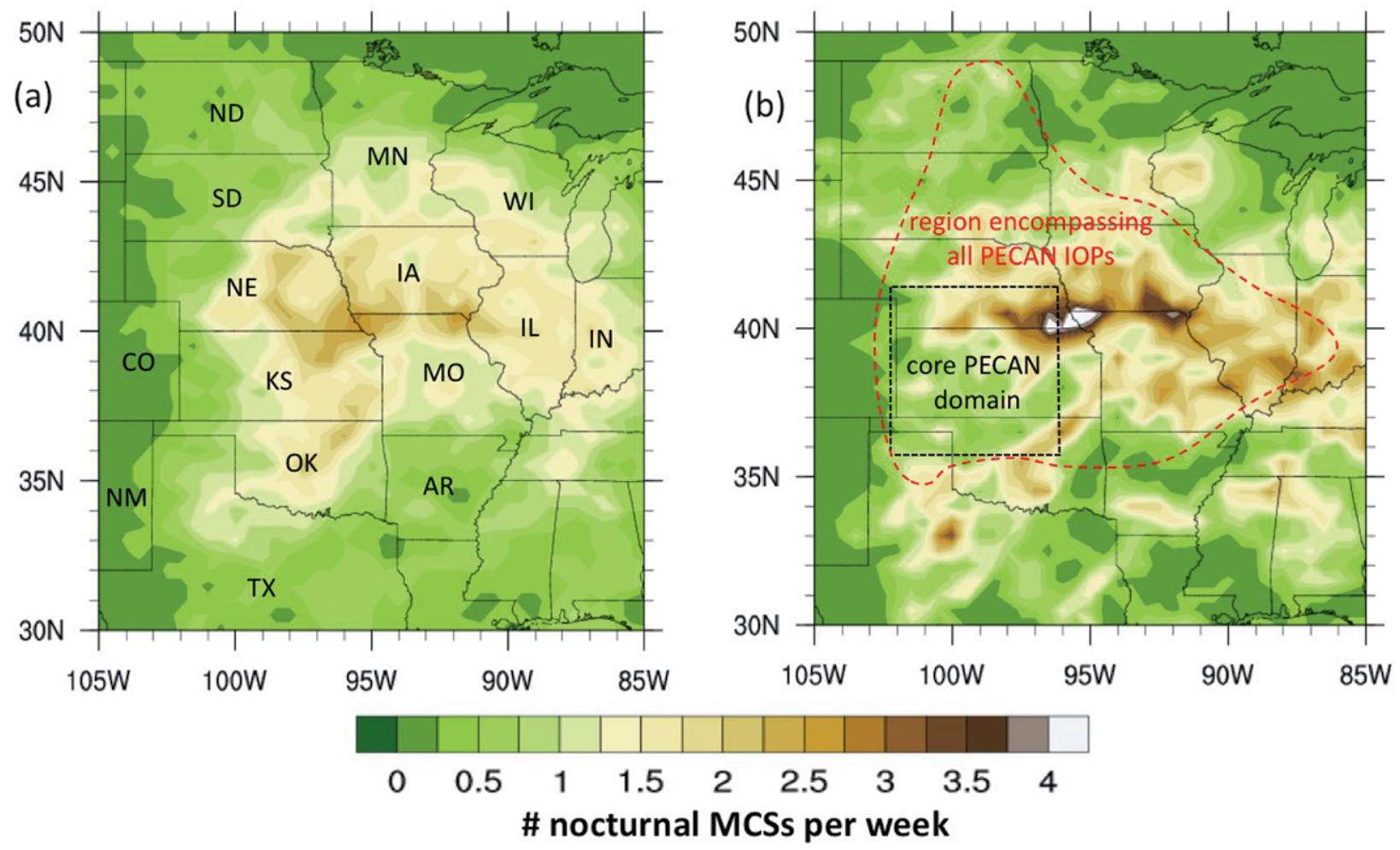

Fig. I. Frequency of nocturnal MCSs (number per week): (a) 6-yr Jun-Aug climatology (2010-15); (b) PECAN period (I Jun-15 Jul 2015).

What explains this nocturnal peak in organized convection and its eastward propagation?

One train of thought focuses on the Rocky Mountains as a source region with feedbacks between the convection and the nocturnal environment that allows convection to become organized and propagate across the plains even as surface-based CAPE vanishes (Heideman and Fritsch 1988; Tripoli and Cotton 1989a,b). A multistep process is envisioned in which mesoscale convection over this region has its origin over the Rocky Mountains, which act as an elevated heat source. Convectively induced deeptropospheric gravity waves emerge over the elevated terrain and propagate eastward, triggering nocturnal convective systems over the plains. In effect, such propagating waves or singular "buoyancy bores" (Mapes 1993; Mapes et al. 2003; Schumacher 2009) may be reenergized through a convective feedback, driven by deep latent heat release in emerging MCSs (Tripoli and Cotton 1989a,b; Tuttle and Davis 2006; Fovell et al. 2006; Trier et al. 2010). Other studies have shown that daytime heating over the elevated terrain
AFFILIATIONS: GEERTS AND Z. WANG-University of Wyoming, Laramie, Wyoming; Parsons, Biggerstaff, Haghi, Klein, AND X. WANG - University of Oklahoma, Norman, Oklahoma; ZIEGLER, CONIGLIO, AND TURNER-NOAA/National Severe Storms Laboratory, Norman, Oklahoma; WECKWERTH—National Center for Atmospheric Research, Boulder, Colorado; CLARK-Millersville University of Pennsylvania, Millersville, Pennsylvania; Demoz-Howard University, Washington, D.C.; FerRare AND NehrIR-NASA Langley Research Center, Hampton, Virginia; Gallus-lowa State University, Ames, lowa; HANESIAK - University of Manitoba, Winnipeg, Manitoba, Canada; KNUPP_-University of Alabama in Huntsville, Huntsville, Alabama; Kosiba AND WURMAN-Center for Severe Weather Research, Boulder, Colorado; McFarquhar AND RAUber-University of Illinois at Urbana-Champaign, Urbana, Illinois; MOORE AND
Pinto-NCAR, Boulder, Colorado; PARKer—North Carolina State University, Raleigh, North Carolina; SCHUMACHER-Colorado State University, Fort Collins, Colorado; Q. WANG—Naval Postgraduate School, Monterey, California

CORRESPONDING AUTHOR E-MAIL: Bart Geerts, geerts@uwyo.edu

The abstract for this article can be found in this issue, following the table of contents.

DOI:10.1175/BAMS-D-I5-00257.I

A supplement to this article is available online (I0.I I75/BAMS-D-I5-00257.2)

In final form 29 July 2016

(C)2017 American Meteorological Society 
of the Rockies generates mesoscale potential vorticity (PV) anomalies that persist even in the absence of latent heating and are advected over the plains at night ( $\mathrm{Li}$ and Smith 2010). The vertical motion associated with these elevated PV anomalies may trigger convection and help to maintain MCSs (e.g., Jirak and Cotton 2007).

An additional key factor for nocturnal MCS development and maintenance is the supply of potentially buoyant air associated with the southerly LLJ (e.g., Pitchford and London 1962; $\mathrm{Pu}$ and Dickinson 2014). This nocturnal jet is common in the central Great Plains in late spring and summer (Fig. 2). MCS development is tightly coupled to the LLJ (Arritt et al. 1997). Long-lived MCSs are often found at the northern terminus of the LLJ along a quasi-stationary, quasizonal baroclinic boundary

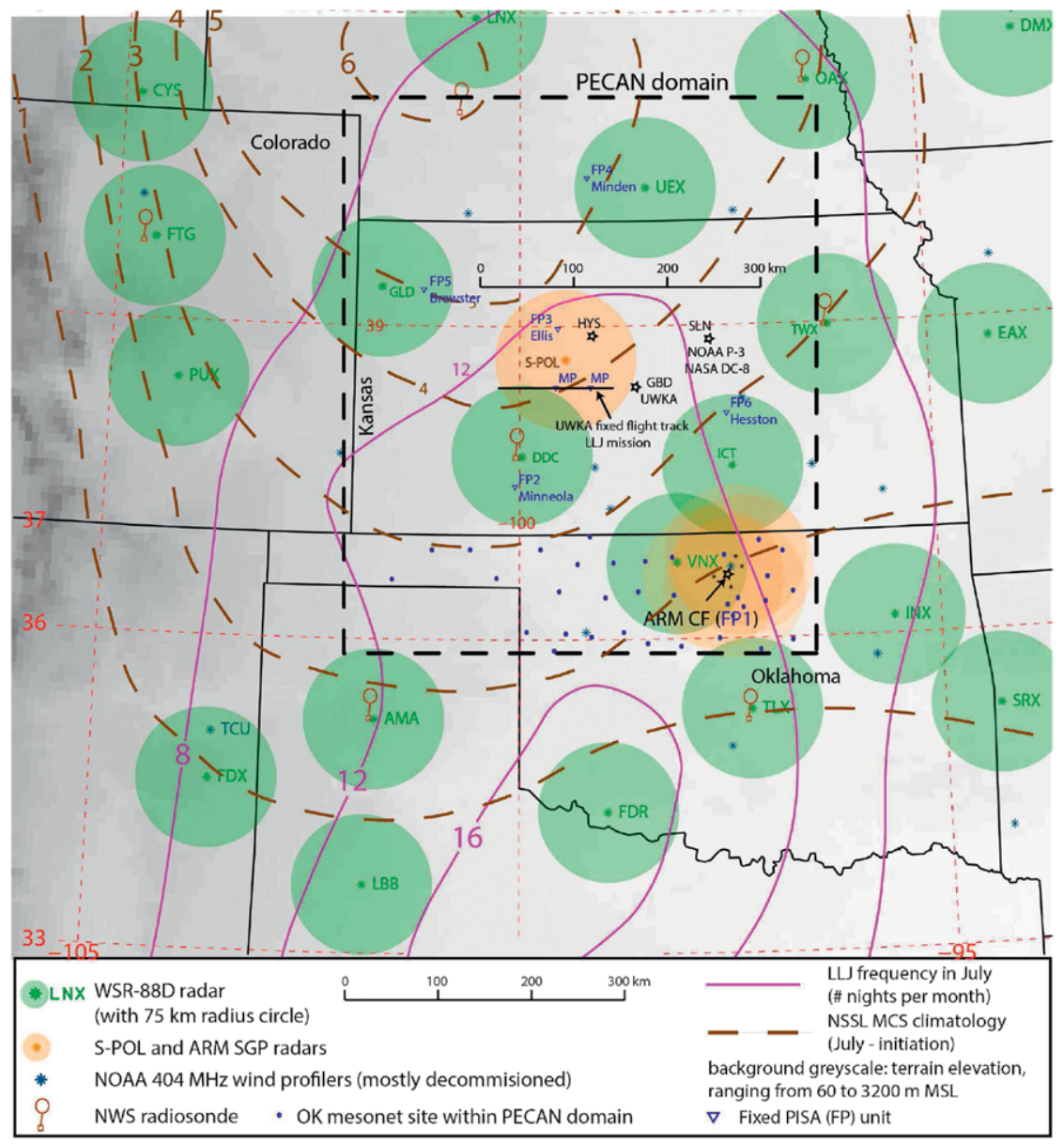

Fig. 2. PECAN experimental design of fixed assets with climatological analyses in the background. See legend for description of contour lines and symbols.

whose mean position may fluctuate between MCS episodes (Tuttle and Davis 2006).

Another feedback mechanism is related to convectively generated cold pools and the subsequent generation of bores. While outflow boundaries are typically surface-based density currents during the daytime, they may either be surface based or elevated at night. The presence of an SBL may result in undular bores propagating ahead of the parent density current (Crook et al. 1990; Carbone et al. 2002; Wilson and Roberts 2006; Coleman and Knupp 2011). Idealized simulations utilizing CPMs have been used to explore this last feedback mechanism, in particular the transition to elevated convection and the formation of a bore (e.g., Parker 2008; French and Parker 2010). This work suggests that an elevated bore can be an integral component of a mature MCS moving through a region with elevated CAPE. In these simulations, bore ascent dominates when the surface-based CAPE vanishes, yet gust-front-driven systems may persist at the surface despite significant boundary layer stabilization (Parker 2008). Several case studies of nocturnal bores show dramatic net displacement of air in the lower troposphere (e.g., Weckwerth et al. 2004; Whiteman et al. 2006; Knupp 2006; Koch et al. 2008; Marsham et al. 2011).

Whatever the dominant mechanism for the initiation, organization, and maintenance of deep convection at night across the Great Plains, weather and climate models poorly capture this nocturnal maximum (e.g., Surcel et al. 2010; Trenberth et al. 2003), and this may have implications downwind (Stensrud 1996) and as far downstream as Europe (Rodwell et al. 2013). Warmseason QPFs are relatively less accurate (Fritsch and Carbone 2004), which is hypothesized to be due in part to the particularly low predictability of nocturnal CI and upscale growth (Davis et al. 2003; Weisman et al. 2008). The lack of skill at reproducing observed MCS behavior is due, in part, to the inability of the convective parameterization schemes to generate or maintain nocturnal convection (Davis et al. 2003; Clark et al. 2007), although operational CPMs show some promise. However, early studies (e.g., Fritsch and Carbone 2004), as well as more recent evaluations of operational 
The PECAN forecast team provided probability forecasts for the occurrence of nocturnal MCSs, bores, and pristine elevated $\mathrm{Cl}$, and qualitatively predicted the strength, location, and duration of the nocturnal LLJ. Probability forecasts were first issued for the broad time window of 0000-1200 UTC as a day 2 forecast during the daily briefing at 2000 UTC and updated during a preliminary day I forecast the next morning at 1630 UTC. For the primary day I forecast at 2000 UTC (3 p.m. local time), MCS probability forecasts were issued for $3-\mathrm{h}$ windows (e.g., 0000-0300, 0300-0600 UTC). Categories of low, moderate, high-moderate, and high were issued representing probabilities of 10\%-30\%, $30 \%-50 \%, 50 \%-70 \%$, and $70 \%-100 \%$, respectively (e.g., Fig. 7). A probabilistic hazard information (PHI) tool

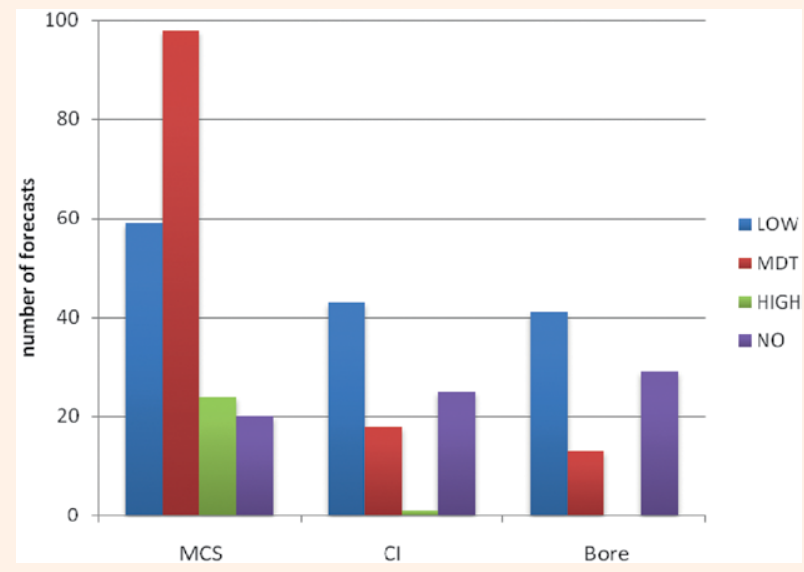

FIG. SBI. Distribution of forecasts issued during PECAN for MCSs, pristine nocturnal $\mathrm{Cl}$, and bores. The forecast probability categories are shown in colored bars with legend at right; NO indicates a forecast of less than $10 \%$ probability of occurrence.
(Karstens et al. 2015) was used by the PECAN field forecasters to help prepare their probabilistic forecast graphics.

Several convection-permitting (typically 3- or 4-km horizontal grid spacing) deterministic models and ensembles were run to facilitate the forecasting. The team typically had access to 0000 UTC runs of WRF models run by NSSL, NCEP, CSU, and the NCAR MPAS model in time for the preliminary day I forecast, as well as the 1200 UTC WRF runs from NSSL and NCEP and the 1200 UTC I-km run (plus 4-km ensembles) from the $\mathrm{OU}$ MAP group. Ensembles were provided at least once per day by NCAR, NSSL, and the OU MAP group. In addition, HRRR runs were available every hour. Probability contours were drawn based on model graphics available from various Internet sites, the PECAN Field Catalog, and the PHI tool (Fig. 8), and the forecast team's experience with weather conditions and model biases.

How to best make use of the huge amount of available model output was a key challenge for the team, especially considering the divergent nature of some model runs. Preliminary analysis (Fig. SBI) shows that the forecasters were more confident issuing higher-probability fore-
CPMs, reveal significant errors in CI timing and location (Kain et al. 2013), system duration, and QPF, in particular during the night in the PECAN region, even over short forecast periods (Pinto et al. 2015).

Certain field campaigns such as IHOP (Weckwerth et al. 2004), BAMEX (Davis et al. 2004), and MPEX (Weisman et al. 2015) collected tantalizing observations of relevance and motivation to PECAN, within the broader PECAN domain. However, IHOP focused on the daytime convective boundary layer and lacked sufficient soundings at night. BAMEX focused on specific aspects of high-end MCSs, such as bow echoes and mesoscale convective vortices (neither of which are studied in PECAN) in an environment generally lacking an LLJ and an SBL. And MPEX focused on upstream conditions and upscale feedbacks to MCS formation and evolution. PECAN was the first campaign to focus expressly on nocturnal CI and MCSs and their environment.
PECAN'S FIVE FOCUS AREAS. The first area of focus (convection initiation) sought to advance knowledge of the processes and conditions leading to pristine nocturnal CI and the initial upscale growth of deep convection. This goal required observation of mesoscale processes such as diabatically forced deep-tropospheric gravity waves, PV anomalies, and frontogenetic circulations that drive vertical displacements and thus alter the profile of stability and shear. Unique to PECAN is the focus on finer-scale processes, such as bores, solitary waves, and parent density currents. In fact, a second PECAN focus (bores) examined how the mesoscale environment modulates the initiation, structure, propagation, and evolution of bores, solitons, and other trapped wave disturbances and sought to determine the inherent role of these systems in the maintenance of nocturnal MCSs. PECAN aimed to detect and understand bores propagating away from their parent cold pool 
casts for MCSs than for the other phenomena. In fact, a high-probability forecast was never issued for bores, and only once for $\mathrm{Cl}$. The team evidenced skill at differentiating the likelihood of MCS occurrence in the 3-h windows, with roughly $30 \%$ of periods with low probability forecasts experiencing an MCS centroid in the low regions, $70 \%$ of moderate forecasts, and $90 \%$ of high forecasts having an MCS centered in the region of the outlined risk (Fig. SB2). However, the centroids of the MCSs often missed the zone of highest assigned risk, instead occurring in the associated lower category of risk nearby. Bore and $\mathrm{Cl}$ events were far more likely to occur than the forecasts indicated. For bores, low (moderate) probabilities verified around $50 \%(90 \%)$ of the time. $\mathrm{Cl}$ happened within the low and moderate probability zones roughly $75 \%$ of the time, with no evidence of an

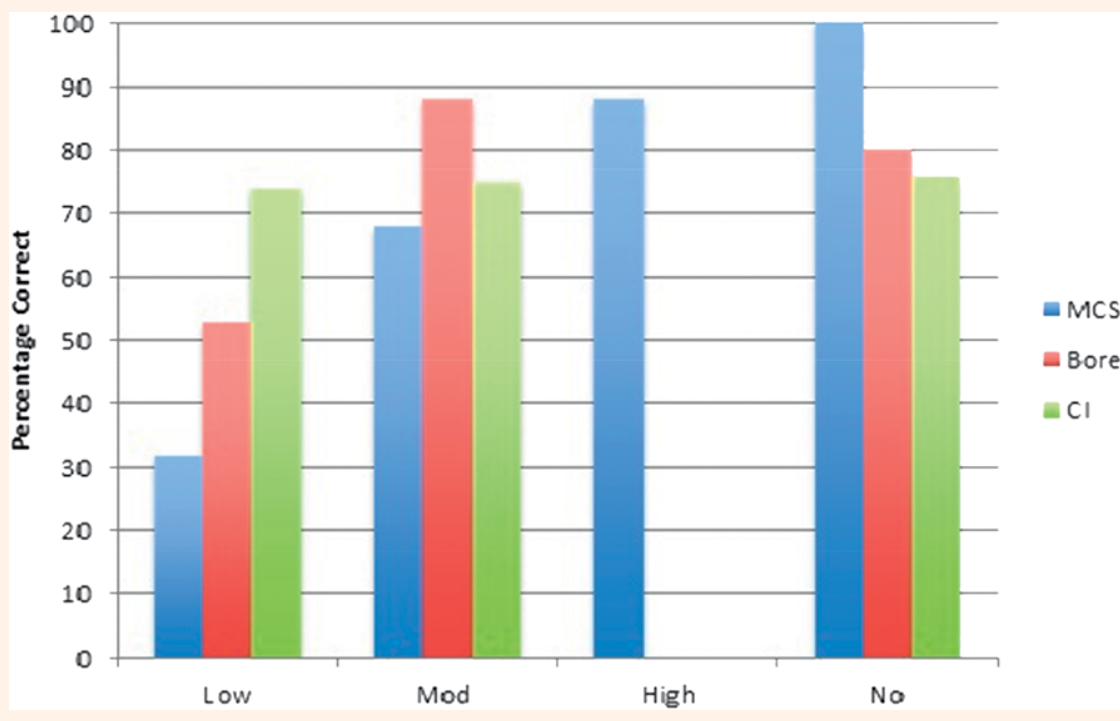

FIG. SB2. Verification of PECAN forecast team probability forecasts for MCSs, bores, $\mathrm{CI}$, as well as null forecasts. ability to distinguish between these two levels.All null forecasts for MCSs verified (no MCS occurred) and roughly $80 \%$ of the $\mathrm{NO} \mathrm{Cl}$ and $\mathrm{NO}$ bore forecasts (Fig. SB2). Given the significant forecast uncertainty, nowcasters were available during each IOP, combining hand-analyzed surface and upper-air charts with radar and satellite observations and new model output guidance to assist in operational decisions.

The focus of PECAN was on nocturnal deep convection which has an a priori probability of being elevated. Precursors of elevated convection were often not evident in either dense surface observations or sparser upper-air data by the time of the daily IOP planning meeting (2000 UTC). Certainly surface, radar, and satellite observations were accounted for, but forecasts were strongly guided by CPM output, notwithstanding considerable model disagreement. The forecasters looked for consensus in the available model output. Forecast performance varied widely: two MCS forecast examples, a poor one and a successful one, are shown online (www.atmos.uwyo .edu/ geerts/pecan/online supplement_BAMS_PECAN forecasting.html). and those that remain an integral part of MCSs. A third focus (low-level jet) addressed the structure and evolution of the nocturnal LLJ, in particular its impact on CI and upscale growth of convection through advection of warm, moist air above the SBL and mesoscale vertical motions. The fourth focus (MCSs) addressed the dynamical and microphysical structure of nocturnal MCSs, including storm- and mesoscale updrafts and downdrafts, internal flows, SBL erosion, cold-pool spreading, bore formation, and the change from gust-front-based to elevated convection. PECAN sampled persistently surface-based and persistently elevated convective updrafts, downdrafts, and cold pools, as well as transitions from surfacebased to elevated and vice versa. Finally, the fifth focus (storm- and MCS-scale NWP) uses PECAN observations to improve prediction of nocturnal CI, MCSs, and, more generally, the diurnal cycle of warm-season precipitation in the Great Plains. Model evaluation occurred during the field phase of PECAN as the field guidance value of several experimental CPMs was assessed (see sidebar on "The challenge of forecasting in support of PECAN operations”). Ongoing and future work ranges from idealized simulations at the scale of the MCS using LES, to the evaluation of physics parameterizations and data assimilation methods used in CPMs, to evaluation of coarser-resolution NWP and global climate models that use convective parameterizations.

\section{PECAN'S INSTRUMENT PLATFORMS.}

During its 1 June-15 July 2015 field phase, PECAN deployed an unprecedented network of integrated profiling systems and scanning radars. PECAN deployed PISA, a mesoscale network of 11 units that obtained the kinematic and thermodynamic profiles of the troposphere, mainly in the lowest $\sim 4 \mathrm{~km}$. Five PISA units were designed as mobile systems (MP), operating 
during IOPs, and six as fixed sites (FP), operating continuously during the field phase. The locations of the FPs are shown in Fig. 2. Partial mobility allows a telescoping spatial array with targetable density variations. No two PISA units were the same (Table 1), although they all measured surface weather and upper-air wind and thermodynamic conditions using radiosondes and remote sensing instruments (except MP5, which only had a remote sensor). Remote sensors included multifrequency passive microwave radiometers (profiles of temperature, humidity, and liquid water), AERI systems (profiles of temperature and humidity), Raman lidars (profiles of specific and relative humidity), and DIAL (profiles of specific humidity). All lidars also operated an elastic channel to detect aerosol layers and cloud edges. Wind profiles were measured by 915- and 449-MHz wind profilers, and in some cases also by Doppler lidars. Some PISA units also included a ceilometer, disdrometer, eddy correlation flux probes, an acoustic sodar, and tethersondes. One MP also had an X-band profiling Doppler radar.

While the four MPs were mostly stationary during IOPs, several MM weather vehicles plus three MG radiosonde launch vehicles operated both nearby and within the target weather during IOPs. A total of 1,439 radiosondes were released in PECAN.

One fixed and up to nine mobile Doppler radars operated in coordination during PECAN IOPs, conducting both volume and RHI scans (Table 2).

Three aircraft operated in PECAN. UWKA, flying below $4 \mathrm{~km}$ MSL, operated the uplooking backscatter WCL, a downlooking CRL (Wang et al. 2011), and in situ probes to measure atmospheric state parameters including pressure perturbations. The NASA DC-8, flying mainly between 7 and $10 \mathrm{~km} \mathrm{MSL}$, operated the NASA Langley LASE DIAL (Browell et al. 1997), to measure water vapor and aerosol profiles below flight level, as well as a profiling Ka-band radar (RainCube). The NASA DC- 8 and UWKA focused on clear-air regions in the vicinity of MCSs to document bores and MCS in-/outflow regions, as well as the LLJ and regions of anticipated CI.

The NOAA P-3 aircraft concentrated on the study of MCS dynamics and microphysics. The P-3 flew a combination of straight legs and spiral vertical profiles in the trailing stratiform region of MCSs. It operated a suite of

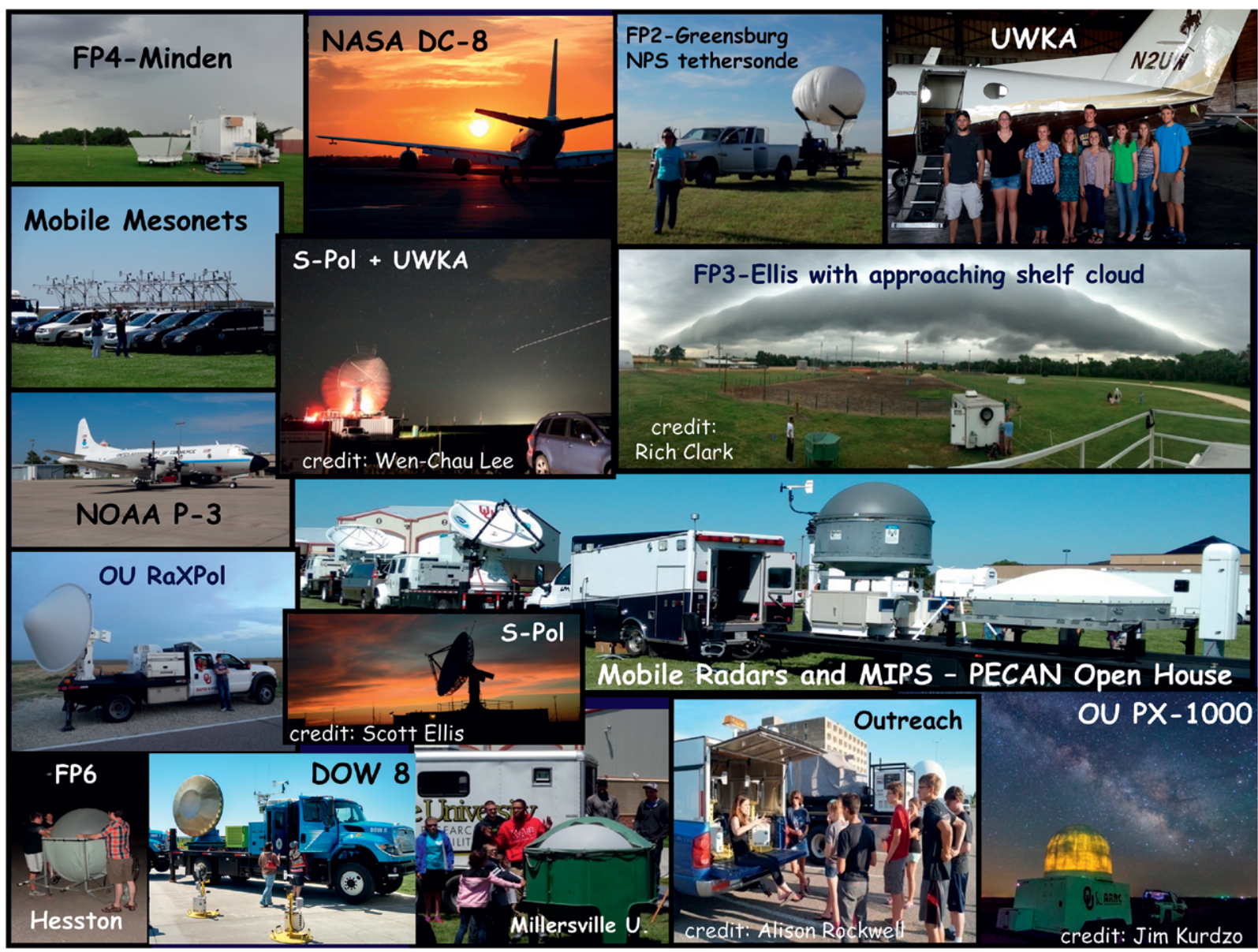

FIG. 3. Photo collage from the field. 
TABle I. The PISA network.

Fixed profiling units (FP): stationary sites that operated continuously throughout PECAN

\begin{tabular}{|c|c|c|c|}
\hline ID & Location & Instrument source & Instruments \\
\hline \multicolumn{4}{|c|}{ Fixed profiling units (FP): stationary sites that operated continuously throughout PECAN } \\
\hline \multirow[t]{2}{*}{ FPI } & $\begin{array}{l}\text { Lamont, Oklahoma (ARM } \\
\text { SGP Central Facility) }\end{array}$ & DOE ARM & \multirow{2}{*}{$\begin{array}{l}\text { Doppler lidar, Raman lidar, AERI, MWR, } \\
\text { surface station with fluxes, radiosonde, } \\
\text { four } 915-\mathrm{MHz} \text { WPs with an average spac- } \\
\text { ing of } 10 \mathrm{~km}, \mathrm{C} \text {-band scanning radar }\end{array}$} \\
\hline & $36.61^{\circ} \mathrm{N}, 97.49^{\circ} \mathrm{W}$ & & \\
\hline FP2 & Greensburg, Kansas & Naval Postgraduate School & $\begin{array}{l}\text { Multilevel mean and flux tower (up to } 16 \\
\mathrm{~m} \text { AGL), low-level tethersonde profiles of } \\
\text { mean met variables, ceilometer, radio- } \\
\text { sonde, and sodar }\end{array}$ \\
\hline & \multirow[t]{4}{*}{$37.61^{\circ} \mathrm{N}, 99.28^{\circ} \mathrm{W}$} & Howard University & Doppler lidar \\
\hline & & $\begin{array}{l}\text { University of Maryland, Baltimore } \\
\text { County }\end{array}$ & $\begin{array}{l}\text { Doppler lidar, backscatter lidar, MWR, } \\
\text { radiosonde, and surface station }\end{array}$ \\
\hline & & DOE ARM & AERI \\
\hline & & NASA GSFC & $\begin{array}{l}\text { Raman lidar, Doppler lidar, X-band profil- } \\
\text { ing radar, GPS ground station for PWV }\end{array}$ \\
\hline \multirow[t]{4}{*}{ FP3 } & Ellis, Kansas & NCAR/EOL & $\begin{array}{l}\text { ISS 449-MHz WP, water vapor DIAL, } \\
\text { GPS ground station for PWV, surface } \\
\text { meteorology, disdrometer, all-sky camera }\end{array}$ \\
\hline & $38.96^{\circ} \mathrm{N}, 99.57^{\circ} \mathrm{W}$ & Millersville University & $\begin{array}{l}\text { Tethersonde profiles of meteorologi- } \\
\text { cal variables/turbulence, surface station } \\
\text { with fluxes, backscatter lidar, radiosonde, } \\
\text { and sodar with radio acoustic sounding } \\
\text { system }\end{array}$ \\
\hline & & University of Manitoba & MWR and Doppler lidar \\
\hline & & DOE ARM & AERI \\
\hline \multirow[t]{2}{*}{ FP4 } & Minden, Nebraska & NCAR/EOL & $\begin{array}{l}\text { ISS with } 915-\mathrm{MHz} \text { WP, radiosonde, ceil- } \\
\text { ometer, surface station with fluxes, GPS } \\
\text { ground station for PWV }\end{array}$ \\
\hline & $40.52^{\circ} \mathrm{N}, 98.95^{\circ} \mathrm{W}$ & DOE ARM & AERI \\
\hline \multirow[t]{2}{*}{ FP5 } & Brewster, Kansas & NCAR/EOL & $\begin{array}{l}\text { ISS with } 915-\mathrm{MHz} \text { WP, sodar, radiosonde, } \\
\text { surface station with fluxes, GPS ground } \\
\text { station for PWV }\end{array}$ \\
\hline & $39.38^{\circ} \mathrm{N}, 101.37^{\circ} \mathrm{W}$ & DOE ARM & AERI \\
\hline \multirow[t]{2}{*}{ FP6 } & Hesston, Kansas & University of Manitoba & MWR, wind lidar \\
\hline & $38.14^{\circ} \mathrm{N}, 97.44^{\circ} \mathrm{W}$ & DOE ARM & AERI, radiosonde, and surface station \\
\hline \multicolumn{4}{|c|}{ Mobile profiling units (MP): operated during IOPs only } \\
\hline MPI & Variable & OU/NSSL & $\begin{array}{l}\text { "CLAMPS”: AERI, MWR, Doppler lidar, } \\
\text { radiosonde, and surface station }\end{array}$ \\
\hline MP2 & Variable & UAH & $\begin{array}{l}\text { "MIPS”: Doppler lidar, 915-MHz WP, } \\
\text { MWR, ceilometer, X-band profiling radar, } \\
\text { radiosonde, and surface station }\end{array}$ \\
\hline \multirow[t]{2}{*}{ MP3 } & Variable & University of Wisconsin-Madison & $\begin{array}{l}\text { "SPARC": AERI, high-spectral-resolution } \\
\text { lidar, radiosonde, and surface station }\end{array}$ \\
\hline & & DOE ARM & Doppler lidar \\
\hline MP4 & Variable & NCAR/EOL & $\begin{array}{l}\text { "MISS": Mobile ISS with } 915-\mathrm{MHz} \text { WP, } \\
\text { radiosonde, and surface station }\end{array}$ \\
\hline MP5 & Variable & NPS/OU & “TWOLF”: Doppler lidar \\
\hline
\end{tabular}

FPI Lamont, Oklahoma (ARM DOE ARM SGP Central Facility)

$36.61^{\circ} \mathrm{N}, 97.49^{\circ} \mathrm{W}$

FP2 Greensburg, Kansas Naval Postgraduate School

\begin{tabular}{|c|c|c|c|}
\hline ID & Location & Instrument source & Instruments \\
\hline \multicolumn{4}{|c|}{ Fixed profiling units (FP): stationary sites that operated continuously throughout PECAN } \\
\hline \multirow[t]{2}{*}{ FPI } & $\begin{array}{l}\text { Lamont, Oklahoma (ARM } \\
\text { SGP Central Facility) }\end{array}$ & DOE ARM & \multirow{2}{*}{$\begin{array}{l}\text { Doppler lidar, Raman lidar, AERI, MWR, } \\
\text { surface station with fluxes, radiosonde, } \\
\text { four } 915-M H z \text { WPs with an average spac- } \\
\text { ing of } 10 \mathrm{~km}, \mathrm{C} \text {-band scanning radar }\end{array}$} \\
\hline & $36.61^{\circ} \mathrm{N}, 97.49^{\circ} \mathrm{W}$ & & \\
\hline \multirow[t]{5}{*}{ FP2 } & Greensburg, Kansas & Naval Postgraduate School & $\begin{array}{l}\text { Multilevel mean and flux tower (up to } 16 \\
\mathrm{~m} \text { AGL), low-level tethersonde profiles of } \\
\text { mean met variables, ceilometer, radio- } \\
\text { sonde, and sodar }\end{array}$ \\
\hline & \multirow[t]{4}{*}{$37.61^{\circ} \mathrm{N}, 99.28^{\circ} \mathrm{W}$} & Howard University & Doppler lidar \\
\hline & & $\begin{array}{l}\text { University of Maryland, Baltimore } \\
\text { County }\end{array}$ & $\begin{array}{l}\text { Doppler lidar, backscatter lidar, MWR, } \\
\text { radiosonde, and surface station }\end{array}$ \\
\hline & & DOE ARM & AERI \\
\hline & & NASA GSFC & $\begin{array}{l}\text { Raman lidar, Doppler lidar, X-band profil- } \\
\text { ing radar, GPS ground station for PWV }\end{array}$ \\
\hline \multirow[t]{4}{*}{ FP3 } & Ellis, Kansas & NCAR/EOL & $\begin{array}{l}\text { ISS 449-MHz WP, water vapor DIAL, } \\
\text { GPS ground station for PWV, surface } \\
\text { meteorology, disdrometer, all-sky camera }\end{array}$ \\
\hline & $38.96^{\circ} \mathrm{N}, 99.57^{\circ} \mathrm{W}$ & Millersville University & $\begin{array}{l}\text { Tethersonde profiles of meteorologi- } \\
\text { cal variables/turbulence, surface station } \\
\text { with fluxes, backscatter lidar, radiosonde, } \\
\text { and sodar with radio acoustic sounding } \\
\text { system }\end{array}$ \\
\hline & & University of Manitoba & MWR and Doppler lidar \\
\hline & & DOE ARM & AERI \\
\hline \multirow[t]{2}{*}{ FP4 } & Minden, Nebraska & NCAR/EOL & $\begin{array}{l}\text { ISS with } 915-\mathrm{MHz} \text { WP, radiosonde, ceil- } \\
\text { ometer, surface station with fluxes, GPS } \\
\text { ground station for PWV }\end{array}$ \\
\hline & $40.52^{\circ} \mathrm{N}, 98.95^{\circ} \mathrm{W}$ & DOE ARM & AERI \\
\hline \multirow[t]{2}{*}{ FP5 } & Brewster, Kansas & NCAR/EOL & $\begin{array}{l}\text { ISS with } 915-\mathrm{MHz} \text { WP, sodar, radiosonde, } \\
\text { surface station with fluxes, GPS ground } \\
\text { station for PWV }\end{array}$ \\
\hline & $39.38^{\circ} \mathrm{N}, 101.37^{\circ} \mathrm{W}$ & DOE ARM & AERI \\
\hline \multirow[t]{2}{*}{ FP6 } & Hesston, Kansas & University of Manitoba & MWR, wind lidar \\
\hline & $38.14^{\circ} \mathrm{N}, 97.44^{\circ} \mathrm{W}$ & DOE ARM & AERI, radiosonde, and surface station \\
\hline \multicolumn{4}{|c|}{ Mobile profiling units (MP): operated during IOPs only } \\
\hline MPI & Variable & OU/NSSL & $\begin{array}{l}\text { "CLAMPS": AERI, MWR, Doppler lidar, } \\
\text { radiosonde, and surface station }\end{array}$ \\
\hline MP2 & Variable & UAH & $\begin{array}{l}\text { "MIPS”: Doppler lidar, } 915-\mathrm{MHz} \text { WP, } \\
\text { MWR, ceilometer, X-band profiling radar, } \\
\text { radiosonde, and surface station }\end{array}$ \\
\hline \multirow[t]{2}{*}{ MP3 } & Variable & University of Wisconsin-Madison & $\begin{array}{l}\text { "SPARC”: AERI, high-spectral-resolution } \\
\text { lidar, radiosonde, and surface station }\end{array}$ \\
\hline & & DOE ARM & Doppler lidar \\
\hline MP4 & Variable & NCAR/EOL & $\begin{array}{l}\text { "MISS": Mobile ISS with } 915-\mathrm{MHz} \text { WP, } \\
\text { radiosonde, and surface station }\end{array}$ \\
\hline MP5 & Variable & NPS/OU & “TWOLF”: Doppler lidar \\
\hline
\end{tabular}

FP3 Ellis, Kansas NCAR/EOL

$38.96^{\circ} \mathrm{N}, 99.57^{\circ} \mathrm{W} \quad$ Millersville University

\begin{tabular}{|c|c|c|c|}
\hline ID & Location & Instrument source & Instruments \\
\hline \multicolumn{4}{|c|}{ Fixed profiling units (FP): stationary sites that operated continuously throughout PECAN } \\
\hline \multirow[t]{2}{*}{ FPI } & $\begin{array}{l}\text { Lamont, Oklahoma (ARM } \\
\text { SGP Central Facility) }\end{array}$ & DOE ARM & \multirow{2}{*}{$\begin{array}{l}\text { Doppler lidar, Raman lidar, AERI, MWR, } \\
\text { surface station with fluxes, radiosonde, } \\
\text { four } 915-\mathrm{MHz} \text { WPs with an average spac- } \\
\text { ing of } 10 \mathrm{~km}, \mathrm{C} \text {-band scanning radar }\end{array}$} \\
\hline & $36.61^{\circ} \mathrm{N}, 97.49^{\circ} \mathrm{W}$ & & \\
\hline \multirow[t]{5}{*}{$\mathrm{FP} 2$} & Greensburg, Kansas & Naval Postgraduate School & $\begin{array}{l}\text { Multilevel mean and flux tower (up to } 16 \\
\mathrm{~m} \text { AGL), low-level tethersonde profiles of } \\
\text { mean met variables, ceilometer, radio- } \\
\text { sonde, and sodar }\end{array}$ \\
\hline & \multirow[t]{4}{*}{$37.61^{\circ} \mathrm{N}, 99.28^{\circ} \mathrm{W}$} & Howard University & Doppler lidar \\
\hline & & $\begin{array}{l}\text { University of Maryland, Baltimore } \\
\text { County }\end{array}$ & $\begin{array}{l}\text { Doppler lidar, backscatter lidar, MWR, } \\
\text { radiosonde, and surface station }\end{array}$ \\
\hline & & DOE ARM & AERI \\
\hline & & NASA GSFC & $\begin{array}{l}\text { Raman lidar, Doppler lidar, X-band profil- } \\
\text { ing radar, GPS ground station for PWV }\end{array}$ \\
\hline \multirow[t]{4}{*}{ FP3 } & Ellis, Kansas & NCAR/EOL & $\begin{array}{l}\text { ISS 449-MHz WP, water vapor DIAL, } \\
\text { GPS ground station for PWV, surface } \\
\text { meteorology, disdrometer, all-sky camera }\end{array}$ \\
\hline & $38.96^{\circ} \mathrm{N}, 99.57^{\circ} \mathrm{W}$ & Millersville University & $\begin{array}{l}\text { Tethersonde profiles of meteorologi- } \\
\text { cal variables/turbulence, surface station } \\
\text { with fluxes, backscatter lidar, radiosonde, } \\
\text { and sodar with radio acoustic sounding } \\
\text { system }\end{array}$ \\
\hline & & University of Manitoba & MWR and Doppler lidar \\
\hline & & DOE ARM & AERI \\
\hline \multirow[t]{2}{*}{ FP4 } & Minden, Nebraska & NCAR/EOL & $\begin{array}{l}\text { ISS with } 915-M H z W P \text {, radiosonde, ceil- } \\
\text { ometer, surface station with fluxes, GPS } \\
\text { ground station for PWV }\end{array}$ \\
\hline & $40.52^{\circ} \mathrm{N}, 98.95^{\circ} \mathrm{W}$ & DOE ARM & AERI \\
\hline \multirow[t]{2}{*}{ FP5 } & Brewster, Kansas & NCAR/EOL & $\begin{array}{l}\text { ISS with } 915-\mathrm{MHz} \text { WP, sodar, radiosonde, } \\
\text { surface station with fluxes, GPS ground } \\
\text { station for PWV }\end{array}$ \\
\hline & $39.38^{\circ} \mathrm{N}, 101.37^{\circ} \mathrm{W}$ & DOE ARM & AERI \\
\hline \multirow[t]{2}{*}{ FP6 } & Hesston, Kansas & University of Manitoba & MWR, wind lidar \\
\hline & $38.14^{\circ} \mathrm{N}, 97.44^{\circ} \mathrm{W}$ & DOE ARM & AERI, radiosonde, and surface station \\
\hline \multicolumn{4}{|c|}{ Mobile profiling units (MP): operated during IOPs only } \\
\hline MPI & Variable & OU/NSSL & $\begin{array}{l}\text { "CLAMPS": AERI, MWR, Doppler lidar, } \\
\text { radiosonde, and surface station }\end{array}$ \\
\hline MP2 & Variable & UAH & $\begin{array}{l}\text { "MIPS”: Doppler lidar, 9I5-MHz WP, } \\
\text { MWR, ceilometer, X-band profiling radar, } \\
\text { radiosonde, and surface station }\end{array}$ \\
\hline \multirow[t]{2}{*}{ MP3 } & Variable & University of Wisconsin-Madison & $\begin{array}{l}\text { "SPARC": AERI, high-spectral-resolution } \\
\text { lidar, radiosonde, and surface station }\end{array}$ \\
\hline & & DOE ARM & Doppler lidar \\
\hline MP4 & Variable & NCAR/EOL & $\begin{array}{l}\text { “MISS”: Mobile ISS with } 915-\mathrm{MHz} \text { WP, } \\
\text { radiosonde, and surface station }\end{array}$ \\
\hline MP5 & Variable & NPS/OU & “TWOLF”: Doppler lidar \\
\hline
\end{tabular}
four 915-MHz WPs with an average spacing of $10 \mathrm{~km}, \mathrm{C}$-band scanning radar
Doppler lidar, Raman lidar, AERI, MWR, surface station with fluxes, radiosonde,

Multilevel mean and flux tower (up to 16 $m$ AGL), low-level tethersonde profiles of mean met variables, ceilometer, radiosonde, and sodar

Doppler lidar

Doppler lidar, backscatter lidar, MWR, radiosonde, and surface station AERI

Raman lidar, Doppler lidar, X-band profiling radar, GPS ground station for PWV

ISS 449-MHz WP, water vapor DIAL, GPS ground station for PWV, surface meteorology, disdrometer, all-sky camera Tethersonde profiles of meteorological variables/turbulence, surface station and sodar with radio acoustic sounding system AER ISS with 915-MHz WP, radiosonde, ceilometer, surface station with fluxes, GPS

ISS with 915-MHz WP, sodar, radiosonde, surface station with fluxes, GPS ground on for PWV

AERI 


\begin{tabular}{|lllll|}
\hline \multicolumn{4}{|l|}{ TABLE 2. Radars } & operating in PECAN. \\
& Source & Dual-pol? & Mobile/fixed & Frequency \\
\hline Radar & NCAR/EOL & Yes & Fixed & S \\
\hline S-Pol & OU & No & Mobile & C \\
\hline SMART-RI & OU & Yes & Mobile & C \\
\hline SMART-R2 & CSWR & Yes & Mobile & X \\
\hline DOW6 & CSWR & Yes & Mobile & X \\
\hline DOW7 & CSWR & No & Mobile & X \\
\hline DOW8 rapid scan & UAH & Yes & Mobile & X \\
\hline MAX & OU & Yes & Mobile & X \\
\hline RaXPoL & NSSL & Yes & Mobile & X \\
\hline NOXP & NSSL & Yes & Mobile & X \\
\hline PX-1000 & & & & \\
\hline
\end{tabular}

in Fig. 4. This information enabled the different platform crews on the ground and in the air to track their location relative to that of others and enabled the PECAN Operations Center to effectively coordinate all assets. This information is invaluable in post-field research also, as it places any dataset in a space- and time-resolved context containing other PECAN data and operational weather data.

The deployment of mobile platforms, especially mobile scanning radars, at night is not easy, and required precampaign site selection cloud and precipitation particle probes, thermodynamics, kinematics, and pressure sensors, as well as a helically scanning X-band tail Doppler radar with antennas pointing $\sim 20^{\circ}$ fore and aft of the fuselage, allowing either 3D pseudo-dual-Doppler or overdetermined wind syntheses by combining with the proximate ground-based radar radial velocities (Jorgensen et al. 2000).

PECAN DEPLOYMENTS. The weather generally was cooperative for all PECAN objectives. The frequency of nocturnal MCSs was anomalously high (Fig. 1b), and synoptic variations allowed a broad array of nocturnal lower-tropospheric conditions to be sampled (see Fig. ES1 in the online supplement: http://dx.doi.org/I 0.II75/BAMS-D-I5-00257.2). A total of 31 IOPs were conducted during the 45-day field phase. Of those, 14 primarily focused on MCS objectives, 6 on bores, and 11 on either CI or the LLJ, or both. Several IOPs served multiple objectives, either by design or by chance. A variable number of mobile platforms voluntarily participated in "UFOs" on most of the remaining non-IOP nights, mostly in close proximity to the Operations Center in Hays, Kansas (Fig. 2). [Details for all IOPs and UFOs can be found on the PECAN Field Catalog at http://catalog .eol.ucar.edu/pecan (under the tab "Missions").] A collage of photos from the field, including some from the PECAN Open House held in Hays before the start of the campaign, are shown in Fig. 3.

One unique and essential capability in PECAN was the real-time tracking of the location of all mobile platforms on the ground and in the air. Location information was displayed on the PECAN Field Catalog (under the tab "Maps") with a latency of just a few minutes. This Field Catalog map was built on Google OpenStreetMap, allowing many layers of overlays, such as composite radar reflectivity shown and special safety precautions. Specialized digital GIS tools were used to virtually "position and scan" mobile radars to identify and qualify more than 12,000 candidate sites relatively free of blockage by terrain and trees. The resulting PECAN virtual site inventory was viewable on the Field Catalog. This helped coordinators at the Operations Center and mobile radar team leaders in the field to locate good sites, although advance scouting and setup before dark were still warranted. This site inventory will remain useful for future field campaigns.

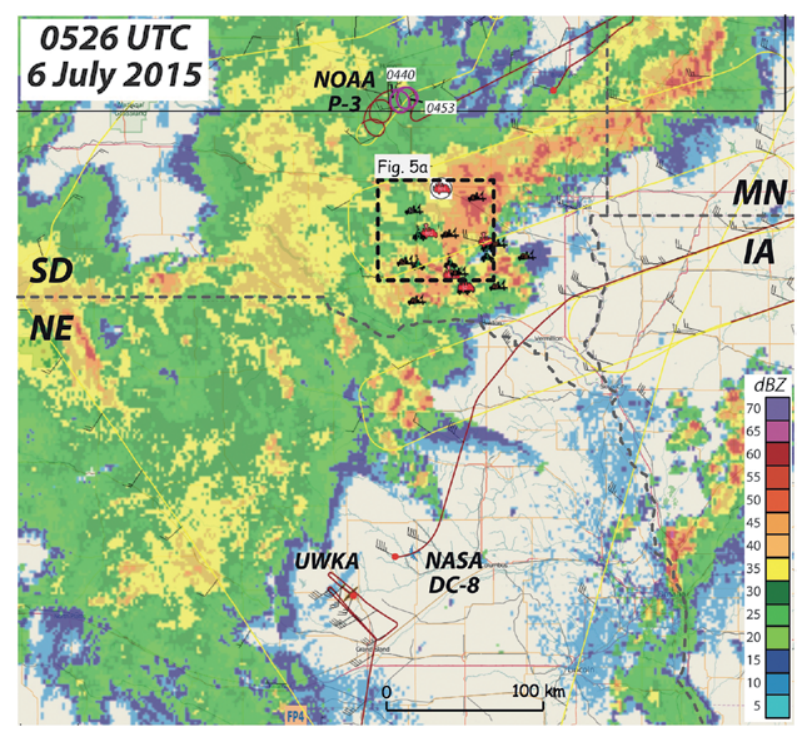

FIG. 4. Deployment of mobile radars, mesonet, and sounding vehicles, plus three aircraft at 0526 UTC 6 Jul 2015, as shown by the real-time Catalog Maps tool. The background map is NEXRAD composite base reflectivity. Aircraft tracks are in yellow, except for the most recent hour of flight, which is shown in red, and except for a section of the NOAA P-3 flight track shown in pink, during which hydrometeor observations shown in Fig. 6 were obtained. The dashed black box locates the domain shown in Fig. 5 a. 
Night shifts invariably led to a lack of sleep, especially so in PECAN because the first forecast meeting was scheduled at $1130 \mathrm{LT}$ and because the mobile crews often faced long drives to or from the IOP area. The collage of scenes from the field in Fig. 3 does not do justice to the many hours people spent in vehicles either ferrying or operating in the field. Clearly PECAN operations would be facilitated by accurate forecasts over time scales from $\sim 6 \mathrm{~h}$ to several days. But it remains difficult to accurately predict the timing and location of CI, development and evolution of MCSs, and undular bores even over relatively short time frames, which of course is a key motivation for the PECAN campaign. The trials and tribulations of forecasting in support of PECAN IOPs are described in the sidebar on forecasting challenges.

In spite of these challenges, the field campaign was a huge success. Numerous phenomena were observed simultaneously by a range of ground-based and airborne remote sensing and in situ platforms, thus providing different perspectives and enabling a more complete 4D depiction. Excellent nocturnal datasets were collected on the initiation, upscale growth, and dissipation of MCSs; on linear squall lines, bow echoes, and MCSs with convective "fingers" protruding into upstream flow; on back-building MCSs (see sidebar on "MCS growth mechanisms"); on the dynamics and microphysics of stratiform regions; on the transition from surface-based to elevated cold pools and inflow regions and vice versa; and on severe weather aspects (hail, heavy rain, severe straight-line winds, and tornadoes). Nocturnal density currents transitioning into undular bores and solitary waves were documented, as well as $\mathrm{CI}$ events associated with elevated convergence, with ascent of the LLJ over a baroclinic zone, and with bores and gravity waves. Several IOPs describe the finescale structure and evolution of LLJs.

Four IOPs discussed below illustrate the types of observations obtained. These IOPs targeted a developing MCS - a bore associated with a MCS, CI, and the LLJ, respectively.

MCS DYNAMICS AND MICROPHYSICS. On 6 July eight mobile radars were deployed in a rather tight polygonal formation, with a typical baseline (radar separation) of $\sim 35 \mathrm{~km}$ (Fig. 4), to sample a mainly internally driven MCS (see sidebar on MCS growth mechanisms). Five MPs and three mobile radiosonde vehicles operated within or near this polygon, roughly along a line parallel with the storm motion. These vehicles are located in Fig. 4. Polygonal close-range radar formations were used commonly for

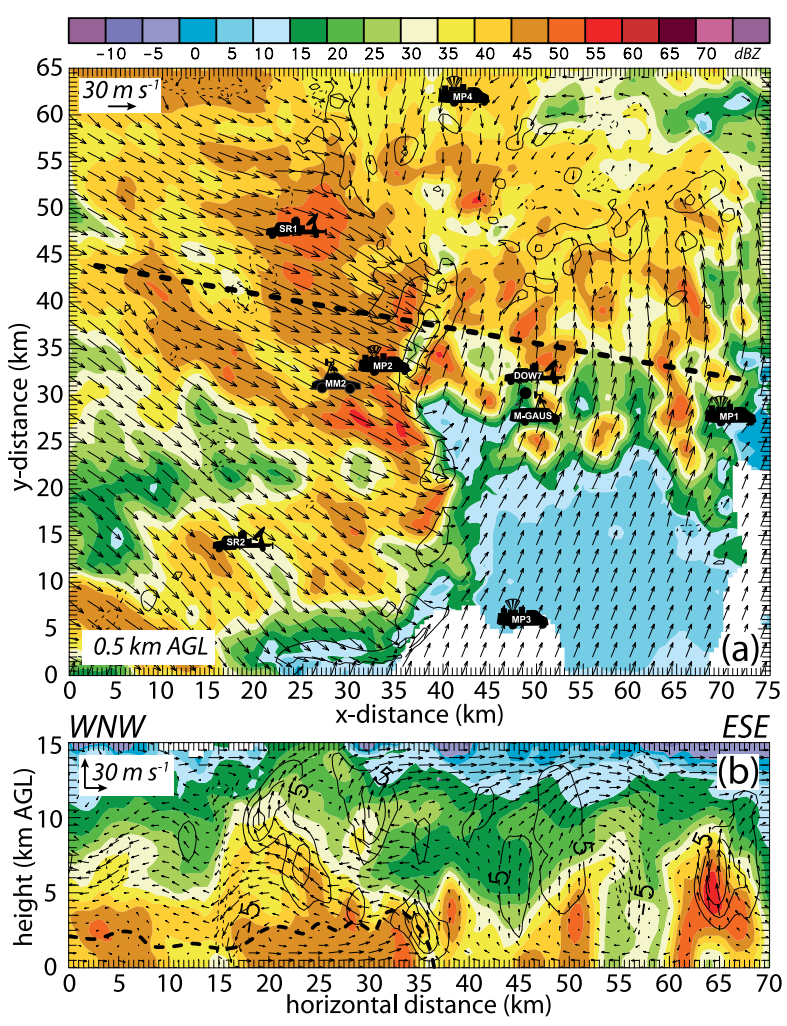

FIG. 5. Triple-Doppler analysis (combining SRI, SR2, and DOW7 mobile radar observations) of reflectivity (dBZ) and wind vectors at 0445 UTC 6 Jul 2015. (a) Horizontal section with ground-relative winds at 0.5 km AGL, within the inset box in Fig. 4 and (b) vertical cross section with MCS-relative winds along the dashed line in (a). Contours are updraft (solid) and downdraft (dashed) magnitudes and have the following contour interval and starting contour values, respectively: (a) 2 and $\pm 2 \mathrm{~m} \mathrm{~s}^{-1}$ and (b) 5 and $\pm 5 \mathrm{~m} \mathrm{~s}^{-1}$. The locations of four mobile PISAs (MPI-4), three mobile radars, a mobile sounding unit (M-GAUS), and a mobile mesonet (MM2) are also shown in (a). The dashed curve in (b) is the estimated cold pool top based on thermal continuity principles (Ziegler 2013).

MCS missions during PECAN to allow either tripleor multi-Doppler overdetermined wind syntheses of the 3D airflow field (Ziegler 2013), as illustrated in Fig. 5 for this MCS. Cold outflow air associated with this MCS produced strong horizontal winds and multiple updraft bands along the gust front (Fig. 5a). The strong winds are indicative of a mainly internally driven MCS structure that intersects and undercuts the convective line of the mainly externally driven MCS to the north and east between the SR1 and DOW7 radars at the analysis time of Fig. 5. (The two types of MCSs are described in the sidebar on MCS growth mechanisms.) An intense rotorlike secondary circulation containing strong low-level straight-line winds of up to $35 \mathrm{~m} \mathrm{~s}^{-1}$ (i.e., severe winds) is evident 
The organization and growth of deep convection from discrete or weakly organized cells into a fully formed convective system can result from processes both external and internal to the convective system. In their review of MCSs, Fritsch and Forbes (200I) categorized systems that are primarily organized and maintained by synopticto-mesoscale processes as "type I" and those organized and maintained by internal convective processes as "type 2." For clarity, we refer to these types as "mainly externally driven" and "mainly internally driven," respectively. In the "mainly external" MCSs, features such as the flow of unstable air over a front (e.g., Augustine and Caracena 1994), ascent ahead of an upper-level trough (e.g., Maddox et al. 1979), or a MCV (e.g., Schumacher and Johnson 2009) are primarily responsible for lifting air to its level of free convection over a relatively large area and for many hours. For example, large MCSs regularly occur where a southerly LLJ intersects a west-east-oriented frontal zone (e.g., Laing and Fritsch 2000; Coniglio et al. 2010; Peters and Schumacher 2015). This scenario brings together the necessary ingredients for the persistent development of deep convection, and the vertical wind profile (southerly winds at low levels veering to westerly winds aloft) is favorable for the organization of convection into lines and clusters. Crook and Moncrieff (1988) showed that lifting a mesoscale region of air to saturation resulted in long-lived MCSs, even if that larger-scale lifting was removed after the MCS initially developed.

In mainly internally driven MCSs, on the other hand, the organization and upscale growth of the convective system is driven by processes associated with the convection itself. In the most thoroughly studied of these mechanisms, cold outflow (originating from evaporative cooling and melting of hydrometeors in convective cells, and downward transport of air with lower moist static energy) spreads out near the surface, and ascent at the boundary between this cool air and the ambient unstable air can initiate subsequent convective cells, which reinforce the cold pool, and so forth. In the presence of moderate or strong vertical wind shear, new convective cells are commonly observed to form along the downshear flank of the outflow owing to the shear's interaction with the cold pool's circulation; these processes can lead to highly organized squall lines and bow echoes (e.g., Rotunno et al. 1988; Weisman and Rotunno 2004).

However, in situations where the near-surface layer is stable, such as is often the case at night owing to radiational cooling, the structures that lead to upscale growth and organization of MCSs are more varied. Rather than forming a cold pool that behaves as a density current, cold thunderstorm outflow can instead initiate bores, gravity waves, or a mixture of gravity waves and gravity currents (e.g., Raymond and Rotunno 1989; Haertel et al. 200I). Exactly how these structures interact with their environment to favor or deter the upscale growth and organization of convection is not well understood. Schmidt and Cotton (1990), Parker (2008), and Schumacher (2009) used numerical models to demonstrate scenarios in which convectively generated gravity waves near the surface supported the organization and maintenance of MCSs. However, prior to PECAN, scant observational evidence existed with which to analyze these structures.

The MCSs observed during PECAN illustrated that there exists a continuum between these externally driven and internally driven situations, with sometimes both mechanisms for growth and maintenance occurring in the same case. One example is the 6 July MCS (Figs. 4 and 5). In the early evening, convection was initiated in south-central South Dakota. This convection grew upscale into a coldpool-driven squall line that moved east through the evening. Shortly thereafter, a southwest-northeast-oriented line of convection was initiated in eastern South Dakota along a cold front and within a region of strong mesoscale ascent associated with warm advection. These two convective systems-one that could initially be considered mainly internally driven and one mainly externally driven (Fig. 7) -later merged (Fig. 5) and moved eastward into Minnesota and lowa (see Fig. ES3 in the online supplement: http://dx.doi.org/I0.II75/BAMS -D-I5-00257.2). Understanding the respective roles of large-scale ascent, cold-pool dynamics, and gravity wave dynamics, and how those processes interact with the thermodynamic and kinematic environment, and with each other, to foster the upscale growth and maintenance of this event and other MCSs observed during PECAN is the subject of ongoing investigation. in the lowest $1 \mathrm{~km}$ above ground (Fig. 5b). Note that the portion of the MCS sampled by MM2 (location shown in Fig. 5a) measured peak surface winds of up to only $20 \mathrm{~m} \mathrm{~s}^{-1}$ (not shown) along its east-west transect of the mesoscale cold pool, in contrast with the far stronger radar-analyzed winds in a vertical cross section $\sim 10 \mathrm{~km}$ farther north (Fig. 5b). The surfacebased circulation in this cross section both lifted and transported relatively warm, moist nocturnal SBL air from ahead of the gust front over the convective cold pool (delineated by a dashed black line in Fig. 5b) toward the rear of the fast-moving MCS convective line. Deep gravity wave motions are evident in this front-to-rear current.

Three aircraft were in operation near this MCS (Fig. 4). The UWKA flew narrow racetracks with a leg length of $\sim 50 \mathrm{~km}$ across an outflow boundary barely visible in the composite radar image (Fig. 4). The NOAA P-3 sampled the stratiform and transition regions of the MCS, with spiraling descents and ascents at flight levels ranging between 1.9 and $6.8 \mathrm{~km} \mathrm{AGL}$, and level flight legs at $\sim 2 \mathrm{~km}$ 
AGL following the length of the squall line in the transition region, under guidance of the Operations Center and the P-3's airborne lower-fuselage radar reflectivity imagery. Representative images of hydrometeors obtained by a 2DC probe on the NOAA P-3 during the third spiral flown between 0440 and 0453 UTC 6 July 2015 through the developing trailing stratiform region are shown in Fig. 6. At subfreezing temperatures, aggregate crystals larger than the width of the photodiode array are seen, and many crystals have rounded edges consistent with riming growth, consistent with hydrometeor images obtained in mature trailing stratiform regions during BAMEX (McFarquhar et al. 2007). Solid precipitation particles extend to temperatures as high as $4^{\circ}-5^{\circ} \mathrm{C}$, with the onset of melting below the freezing level being delayed by rapid hydrometeor meltwater evaporation as relative humidity decreases from $90 \%$ to $70 \%$ though the $0^{\circ}-5^{\circ} \mathrm{C}$ layer. At levels below the $4^{\circ} \mathrm{C}$ isotherm, few hydrometeors were noted on this spiral descent because the hydrometeors had not had sufficient time to reach such levels. The data obtained during the formative stages of the stratiform region during PECAN considerably extend the data obtained during BAMEX that emphasized the mature and decaying stratiform regions. This will allow us to extend BAMEX analyses (Smith et al. 2009) to place the microphysical properties (mass contents, concentrations, representative particle sizes and habits, gamma fits to observed size distributions) in context of the evolution stage and radar-observed structure of the convective line and stratiform region.

The DC-8 flew a lawnmower pattern ahead of the organizing convection in this IOP. Specifically, the DC- 8 mapped humidity ahead of the northern mainly externally driven MCS in its early stage, before its merger with the mainly internally driven MCS (Fig. 7). The LASE water vapor profiles revealed a $\sim 200$-km-wide region of high water vapor mixing ratio values in the southerly inflow region during the MCS developing stage, a few hours before the Fig. 4 map time. Surface dewpoints were as high as $22^{\circ}-24^{\circ} \mathrm{C}$ under this moisture dome, which can be seen to grow deeper and more moist toward the incipient MCS (Fig. 7). The LASE precipitable water over a depth with good-quality data (between 1.3 and $5.0 \mathrm{~km} \mathrm{MSL}$ ) varies from $\sim 27 \mathrm{~mm}$ along the margins to $\sim 35 \mathrm{~mm}$ within this dome. Similar values were recorded by pre-MCS radiosondes within this moisture dome (Fig. 5a) over the same depth. The 6 July 2015 case was one of the more successful IOPs in PECAN, in part thanks to the excellent forecast made as early

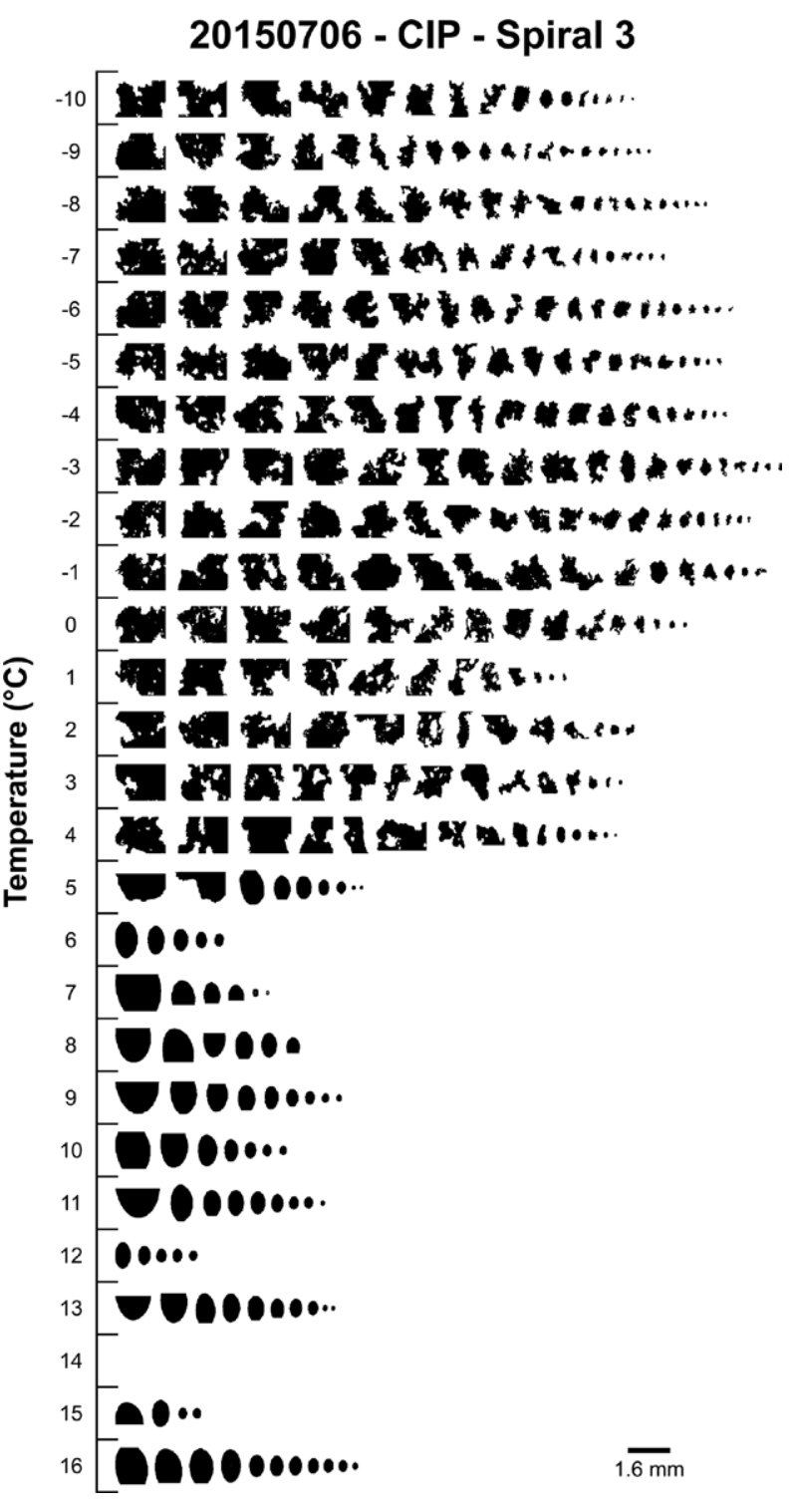

Fig. 6. Representative particles imaged by the 2DC probe during the spiral descent of the NOAA P-3 through the trailing stratiform region between 0440 and 0453 UTC 6 Jul 2015. This flight section is shown in pink in Fig. 4.

as 1600 UTC of the previous day (Fig. 7 and sidebar on forecasting challenges).

UNDULAR BORES. An atmospheric bore is a type of internal gravity wave phenomenon defined as a hydraulic jump that does not transport mass; the denser fluid does not build up behind the bore head like a density current. Depending on bore strength, bores may appear undular (laminar) or turbulent (Rottman and Simpson 1989). A solitary wave typically is a single supercritical gravity wave of elevation, leading an amplitude-ordered wave train ("soliton") in which trailing waves have a much 
smaller amplitude (Koch et al. 2008). Undular bores may evolve into solitons, and the distinction often is not immediately clear; hence, we simply refer to the family of wavelike boundaries on top of the SBL as bore events. Most pre-PECAN bore events described in the literature were encountered by chance. Targeting bores and related wave phenomena is difficult because their development and evolution depend on the strength of the convectively generated cold pool and of the SBL, and on the ambient wind profile, all of which are difficult to predict. A webbased PHI tool, developed originally for the NOAA Hazardous Weather Testbed Spring Experiments and used for MCS and CI

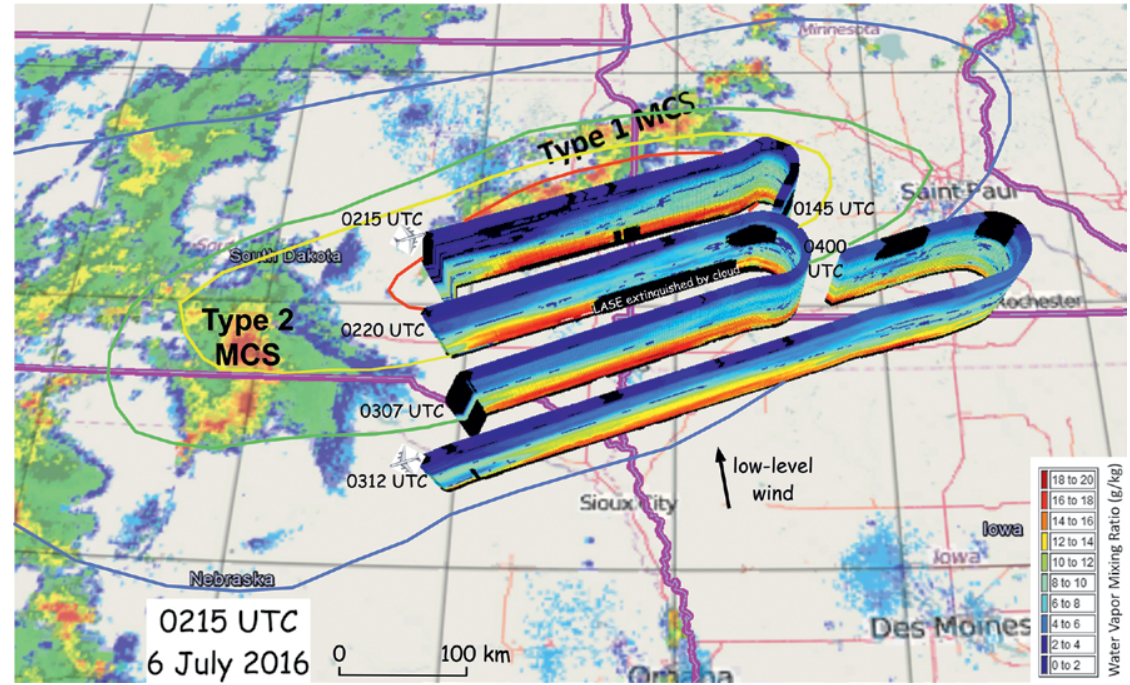

FIG. 7. 3D LASE water vapor distribution upstream of the MCS shown in Fig. 4. The LASE data were collected aboard the NASA DC-8 between 0145 and 0400 UTC 6 Jul, from a flight level of $8.5 \mathrm{~km}$, descending to $6.7 \mathrm{~km} \mathrm{MSL}$ on the last flight leg. The background image is NEXRAD composite base reflectivity at 0215 UTC. The colored closed contours are subjectively estimated probabilities of an MCS between 0300 and 0600 UTC, as produced by the PECAN field forecasters based on data available at 1600 UTC 5 Jul, ranging from low (outer blue contour) through moderate (inner green and yellow contours) to high (inner red contour). The black LASE sections lack data owing to lidar beam extinction by cloud. forecasting, was extended to predict bores as well in PECAN (Karstens et al. 2015; Haghi et al. 2015). The data driving this tool in PECAN were obtained from a 1-km WRF model developed and run in real time by the University of Oklahoma MAP group (Johnson et al. 2015). The PHI tool user selects two points: one in the ambient air and one in the denser, cooler air of the convective outflow. Bore diagnostics are then calculated for this pair of locations. An example is shown in Fig. 8 for 12 July 2015. These diagnostics assess the ability of a density current to generate and maintain a bore, given ambient flow and stability conditions. Figure $8 \mathrm{~b}$ shows whether or not a bore can form, and bore strength (ratio of the bore depth

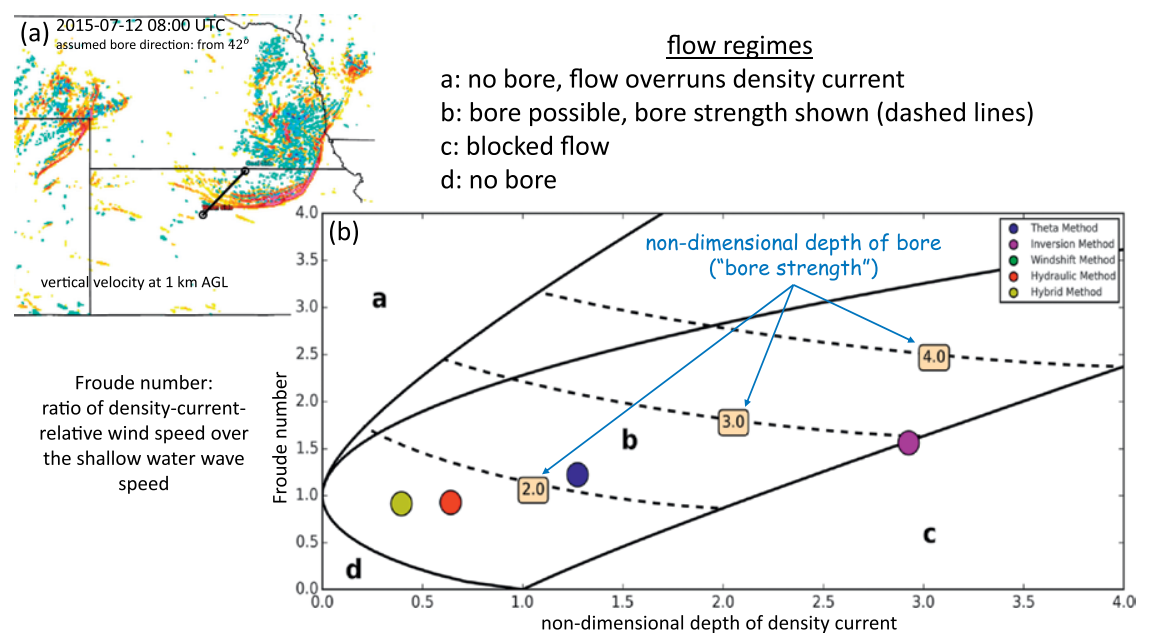

FIG. 8. Demonstration of the methodology behind forecasting atmospheric bores for a bore event on 12 Jul: (a) model vertical motion at I km AGL (red is positive, blue is negative) and (b) bore diagnostic tools calculated from values at the two user-selected end points shown in (a). to the SBL depth), as a function of Froude number and density current depth (also expressed relative to the SBL depth) following Rottman and Simpson (1989). Estimates based on four different methods of interpreting model output are shown in Fig. 8 b. Further bore diagnostics produced by the PHI tool relate to the presence of a wave duct or a critical layer reflecting wave energy (not shown). The main challenges in the use of this tool are its dependence on an accurate prediction of the convective cold pool 

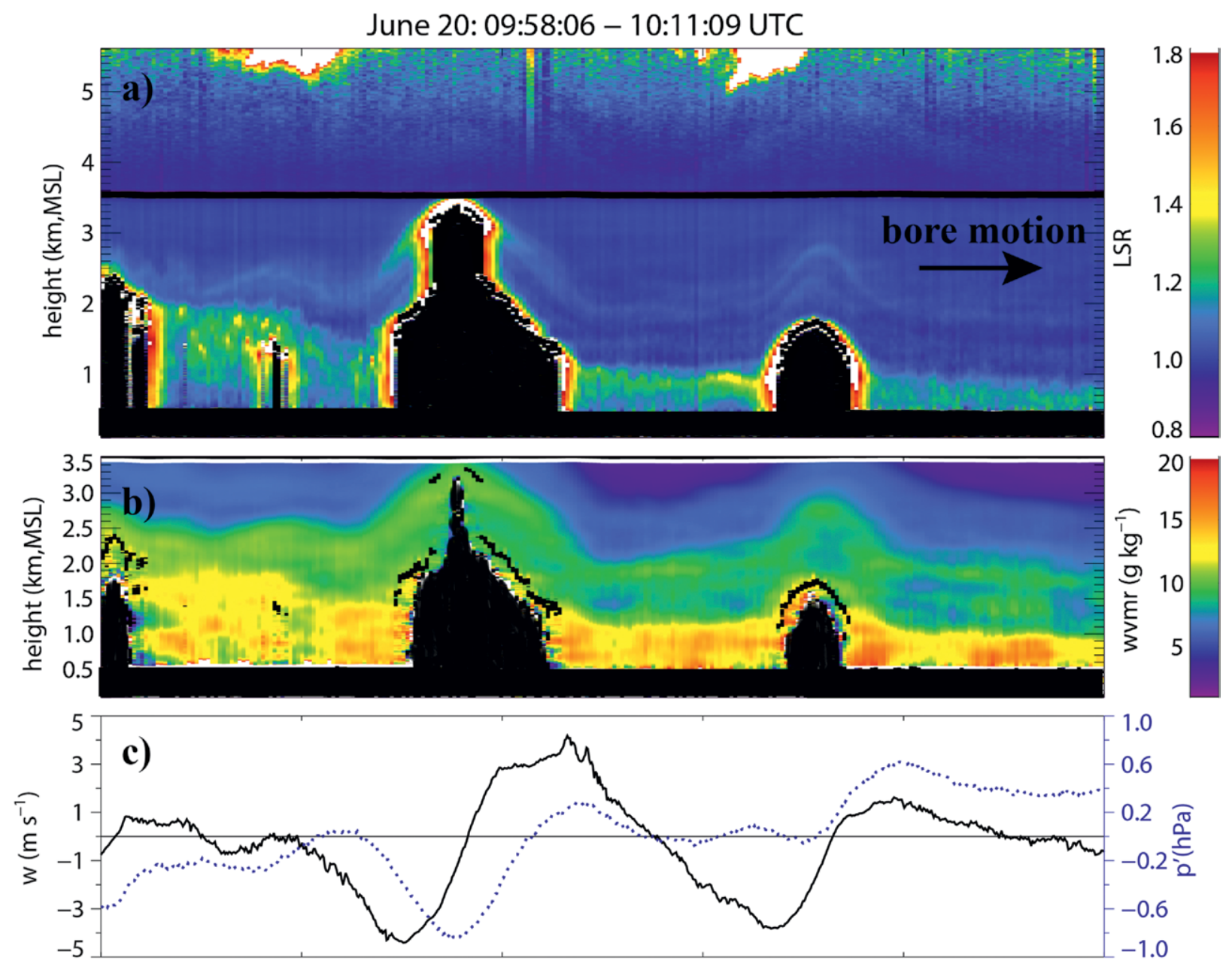

1.0

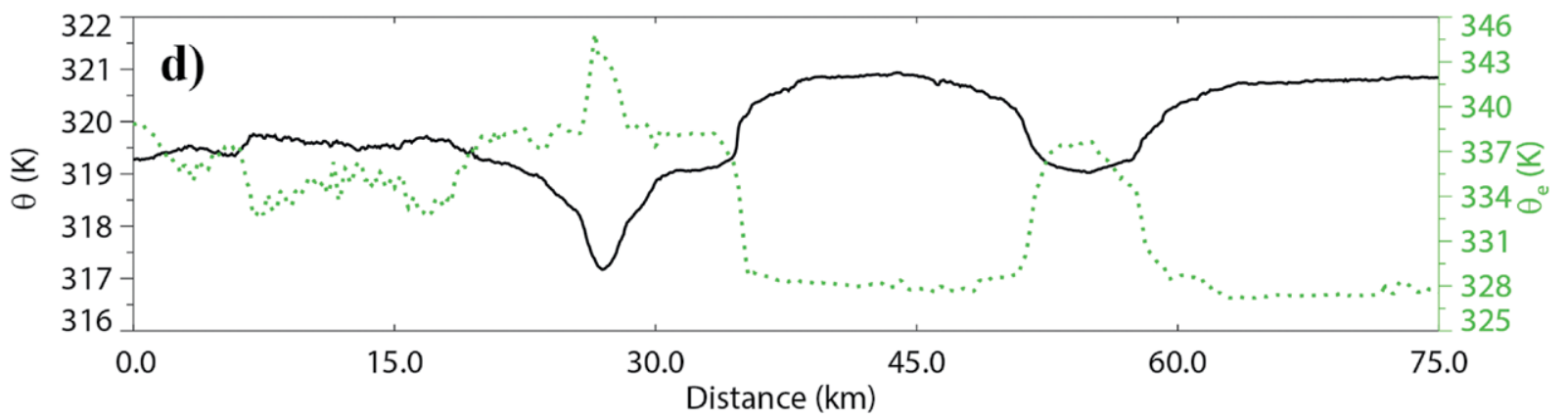

FIG. 9. Transect of a bore encountered by the UWKA on 20 Jun. (a) Lidar scattering ratio obtained from WCL above flight level (3.55 km MSL) and CRL below flight level; (b) CRL water vapor mixing ratio; (c),(d) flightlevel data, including air vertical velocity $w$, perturbation pressure $p$ ', potential temperature $\theta$, and equivalent potential temperature $\theta_{\mathrm{e}}$.

and the SBL and a lack of information regarding forecast uncertainty.

Nocturnal convective cold pools frequently produced bores during PECAN. An undular bore of unusual amplitude emerged from the cold pool associated with a large MCS over Nebraska observed on 20 June 2015. It was sampled by FP4 and the UWKA. The latter documented its transition from an elevated density current to a bore (Fig. 9). In this case the second wave has the greatest amplitude, with vertical velocities of $\pm 4 \mathrm{~m} \mathrm{~s}^{-1}$ at flight level. The nearly 1 -mb pressure deficit in this wave's crest is not hydrostatic, but rather dynamically forced, associated with flow spin in the wave crest. The profiling airborne lidars depict vertical displacements of aerosol and/or humidity layers up to $1.5 \mathrm{~km}$, resulting in clouds in the wave crests, extinguishing the lidar signal (Fig. 9a). The smooth undular structure transitions to a more turbulent structure in 


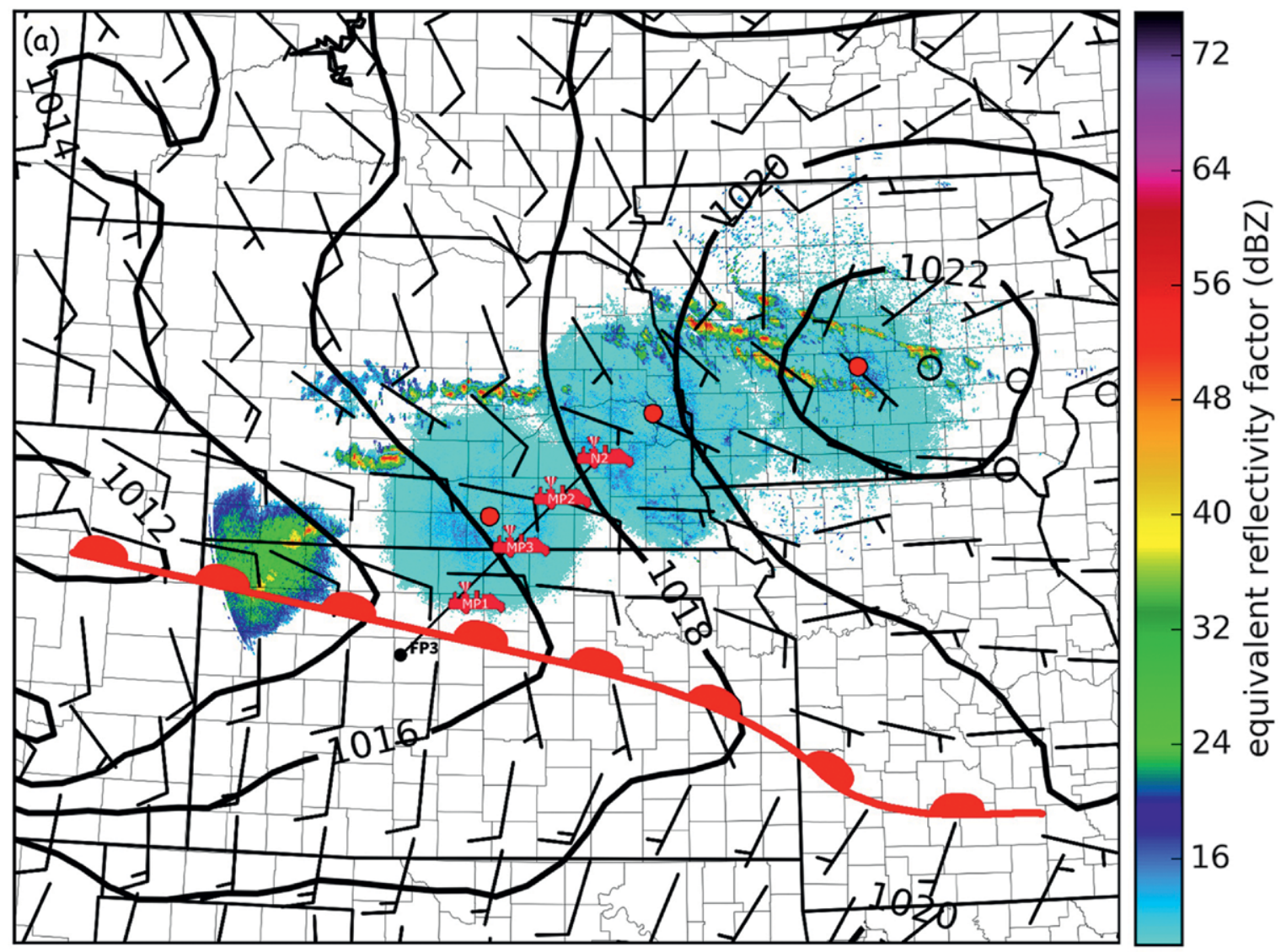

(b) Cross-section from FP3 to N2 at 0300 UTC 24 June 2015

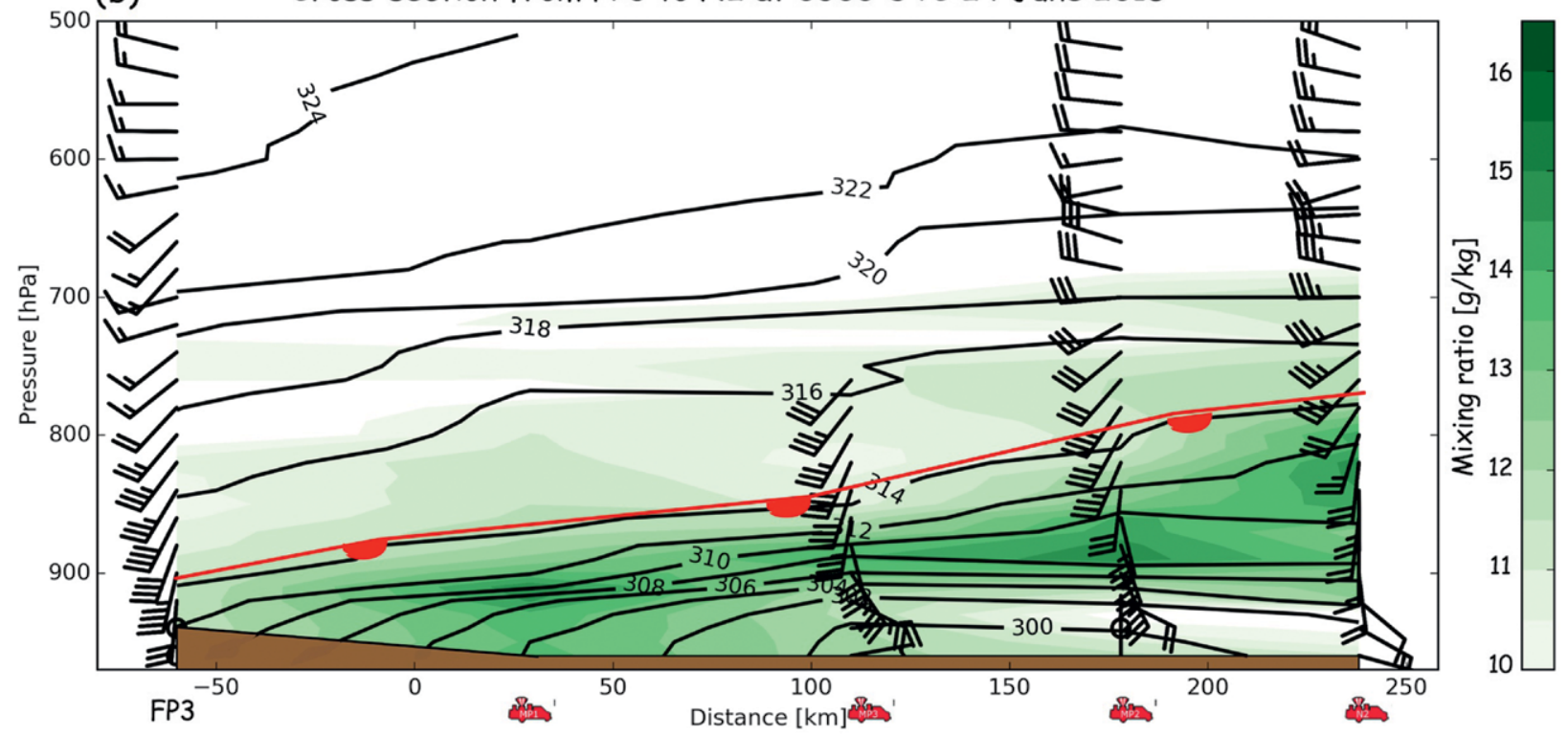

FIG. 10. (a) Surface map at 0600 UTC 24 Jun following $\mathrm{Cl}$, with sea level isobars (solid black), wind barbs (in knots; full barb is $10 \mathrm{kt}$ ) and radar reflectivity from relevant WSR-88Ds (red dots). (b) Vertical cross section from SW to NE across the warm front, based on five radiosondes released at 0300 UTC 24 Jun from the fixed or mobile sites shown in (a). Contours are potential temperature $(\mathrm{K})$, color shades indicate mixing ratio $\left(\mathrm{g} \mathrm{kg}^{-1}\right)$, and wind barbs are plotted at each sounding location (full barb is $10 \mathrm{kt}$ ). 

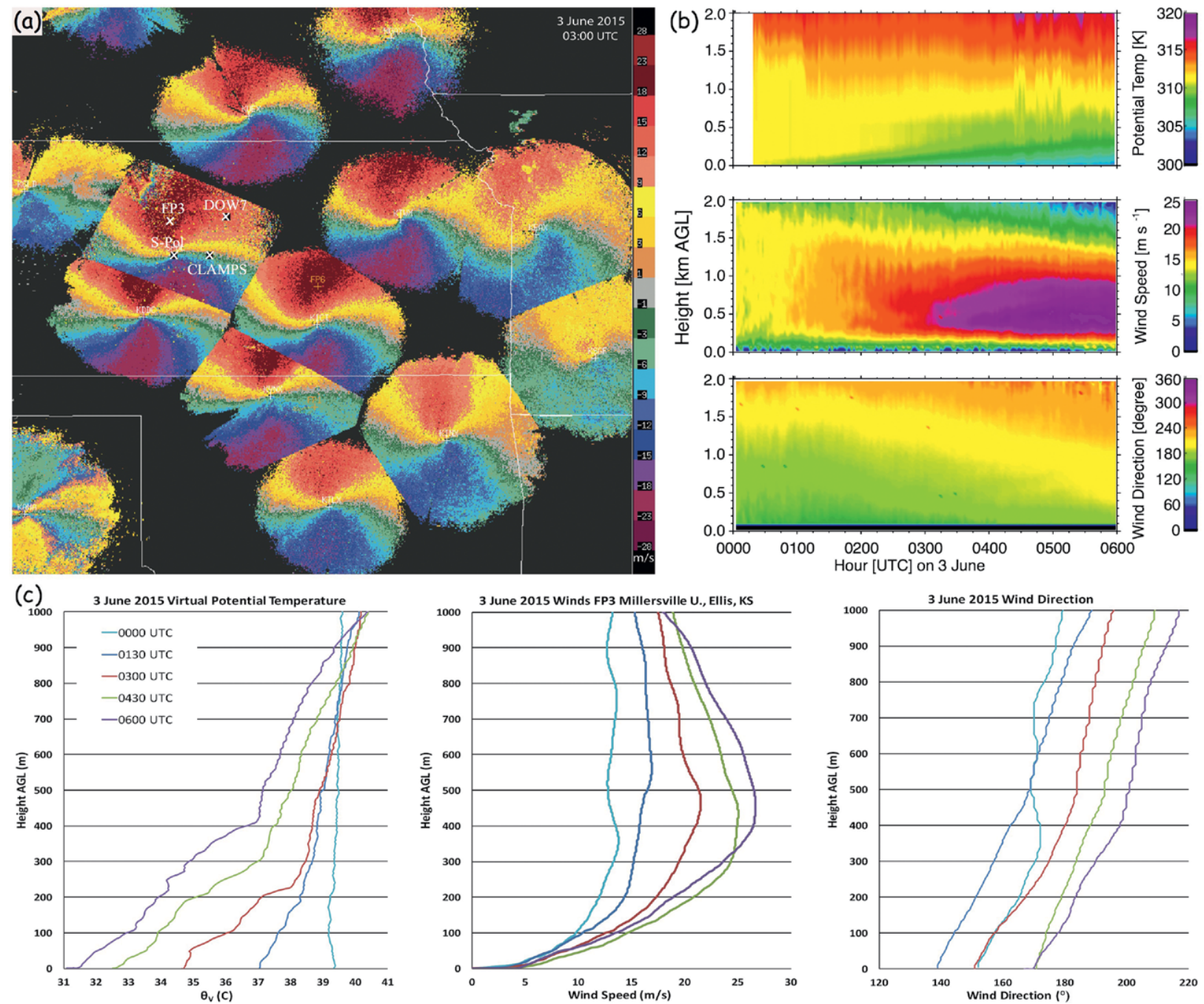

FIG. II. (a) Mosaic base-elevation Doppler velocity field composed of the NEXRADs and S-Pol in the central Great Plains at 0300 UTC 3 Jun. (b) Time-height sections of virtual potential temperature $\theta_{v}$ (from an AERI probe), wind speed, and wind direction (from a Doppler lidar) measured by CLAMPS [location shown in (a)], for 0000-0600 UTC on the same day. (c) Radiosonde profiles of $\theta_{v}$, wind speed, and direction in the 0-I-km AGL layer for the same period, at nearby FP3 [location shown in (a)].

the wake of the second crest, most evident in the LSR signal below flight level (Fig. 9a). The wave crests correspond with relatively cool air (low $\theta$ ) yet with elevated $\theta_{e}$ at flight level (Fig. 9d). This indicates boreinduced lofting of stratified yet potentially unstable air. This instability may be released by bore lifting.

CONVECTION INITIATION. Undular bores propagating away from mature MCS cold pools, such as the one illustrated in Fig. 9, initiated new convection remote from the MCS in a few PECAN IOPs. More commonly bores triggered new convective cells in close proximity to the leading edge of MCSs, cells that rapidly merged into the MCS. Elevated "pristine" CI (i.e., CI not triggered by nearby convection) was observed in many PECAN events. Such nocturnal CI typically is not preceded by a well-defined clear-air radar convergence line, as it is during the daytime (e.g., Wilson and Schreiber 1986); thus, the probability of time- and space-resolved CI forecasts generally was rather low (see sidebar on forecasting challenges). Pristine CI sometimes occurred along mesoscale waves, as evident in animations of S-Pol base reflectivity in clear air. Nocturnal pristine CI also occurred in large-scale baroclinic regions above the SBL-for example, on 24 June (Fig. 10). The radiosonde transect across a warm frontal surface shows sloping isentropes (Fig. 10b). A strong LLJ evident on the SW side of this transect decelerates as it crosses the warm front, resulting in deep moisture convergence along the sloping baroclinic zone (Fig. 10b). Pristine 
CI occurs 1-2 $\mathrm{h}$ after the sounding transect, around 0500 UTC, in bands aligned with the surface warm front but several $100 \mathrm{~km}$ north of it (Fig. 10a). The timing and exact location of the formation of these bands is under investigation. The bands in Iowa then grew upscale between 0600 and 0800 UTC to become a MCS.

THE NOCTURNAL LOW-LEVEL JET. The spatial distribution of the nocturnal LLJ within the PECAN domain is captured beautifully in Fig. 11a on 3 June 2015. The mosaic of base-elevation Doppler velocity displays shown in Fig. 11a includes the WSR-88Ds and S-Pol. At the time shown in Fig. 11a (0300 UTC), the southerly LLJ is strongest in central Kansas, with a peak wind speed of $\sim 22 \mathrm{~m} \mathrm{~s}^{-1}$ at $0.4-0.5 \mathrm{~km}$ AGL. Such velocity displays were used in real time during PECAN to monitor the temporal evolution and spatial distribution of the LLJ during IOPs. Radiosondes launched every $30 \mathrm{~min}$ at some FPs provided documented the detailed vertical structure of the LLJ environment. Time-height transects at the CLAMPS MP (location shown in Fig. 11a) highlight the veering of the wind with time between 0000 and 0600 UTC, and with height, while the SBL deepens (Fig. 11b). The LLJ is strongest toward the end of this time period, near the top of the SBL at $\sim 400 \mathrm{~m}$ AGL. The radiosonde profiles obtained at FP3 for this same period (Fig. 11c) show the growth of the SBL from 200 to $400 \mathrm{~m}$ AGL from 0300 to 0600 UTC and the attendant acceleration and the clockwise inertial turning of the wind field. Maps of base-level Doppler velocity from DOW7 (location shown in Fig. 11a) confirm the veering of the wind with time and height (see Fig. ES2 in the online supplement: http://dx.doi .org/I 0. I I 75/BAMS-D- I5-00257.2).

CONCLUSIONS. PECAN is the first field campaign to focus on nocturnal organized deep convection interacting with the SBL and the LLJ. It also deployed the most extensive networks of mobile radars and of integrated profiling systems to date, providing a great resource for case studies related to MCSs, CI, undular bores, the LLJ, and their interactions. Coordinated measurements during a total of 31 PECAN IOPs would not have been possible without the dedication of some 350 participants, including over 130 graduate and undergraduate students, operating in often challenging conditions at night. Forecasting when and where specific phenomena (MCSs, CI, or bores) would form with enough skill to position mobile crews in advance proved extremely difficult, yet many such phenomena were captured successfully during PECAN.
Various types of bores were found to be ubiquitous in the vicinity of MCSs. The MCSs observed during PECAN show that a continuum exists between "externally driven" (such as by frontal forcing) and "internally driven" (such as by cold-pool forcing) situations. Sometimes both external and internal MCS growth and maintenance mechanisms were found to be operating in a single MCS. PECAN data show that pristine nocturnal CI above a SBL is not uncommon, but such elevated CI is more obscure than $\mathrm{CI}$ in a surface-based convective boundary layer, and its precursors are more difficult to measure. The PECAN dataset will enable novel data assimilation experiments, model development, and will serve as a test bed for a mesoscale network of lower-tropospheric profiling systems.

ACKNOWLEDGMENTS. PECAN was enabled through a series of NSF grants (AGS-1327695, AGS1359726, AGS-1359645, AGS-1359606, AGS-1359098, AGS-1359771, AGS-1442054, ATM-1359703, AGS1359720, AGS-1359698, AGS-1361237, AGS-1237404, and AGS-1359723), the NSF Lower Atmosphere Observing Facilities pool (three DOWs; the UWKA; S-Pol; four NCAR Integrated Sounding Systems, one of them with a 449-MHz wind profiler; and GPS radiosondes), an NSSL grant (deploying the NOXP mobile radar, two mobile mesonets, field forecasting support, and federal staff travel), a NOAA/AOC grant (deploying the P-3 aircraft), a NOAA/OAR grant (all expendables for mobile soundings), a NASA grant (deploying the DC-8 aircraft and several and ground-based lidars and radars), and a DOE grant (a radiosonde unit, five AERIs, a Doppler lidar, and enhanced measurements at FP1). The Canadian Natural Sciences and Engineering Research Council (NSERC) Discovery Grant and Canada Foundation for Innovation (CFI) enabled participation of the University of Manitoba. PECAN would not have been possible without the commitment of many scientists, students, and professional support staff. The National Center for Atmospheric Research is sponsored by the National Science Foundation. The expert field forecasting services of Jack Hales and David Imy (both retired SPC lead forecasters) are gratefully acknowledged. Christopher Karstens adapted NSSL's PHI tool to accommodate bore forecasting and maintained the PHI tool server at NSSL, enabling the field forecasters to run this tool remotely. J. Correia and P. Marsh (SPC) assisted with the development of the LLJ and MCS climatologies shown in Fig. 2. Daniel Stechman developed Fig. 6, Scott Kehler made Fig. 10 and associated animation, and Megan McAuliffe helped with Fig. 11. Matt Flournoy developed the animation for the sidebar on MCS growth mechanisms. 
APPENDIX. List of acronyms.

\begin{tabular}{|c|c|c|c|}
\hline \multirow{3}{*}{$\begin{array}{l}2 \mathrm{DC} \\
\mathrm{AERI}\end{array}$} & 2D cloud & MPEX & Mesoscale Predictability Experiment \\
\hline & \multirow{2}{*}{$\begin{array}{l}\text { Atmospheric emitted radiance inter- } \\
\text { ferometer }\end{array}$} & MWR & Microwave radiometer \\
\hline & & NASA GSFC & National Aeronautics and Space Ad- \\
\hline BAMEX & Bow Echo and MCV Experiment & & ministration Goddard Space Flight \\
\hline CPM & Convection-permitting model & & Center \\
\hline CAPE & Convective available potential energy & NCAR/EOL & National Center for Atmospheric \\
\hline CI & Convection initiation & & Research/Earth Observing Labora- \\
\hline \multirow[t]{2}{*}{ CLAMPS } & Collaborative Lower Atmospheric & & tory \\
\hline & Mobile Profiling System & NCEP & National Centers for Environmental \\
\hline CRL & Compact Raman lidar & & Prediction \\
\hline CSWR & Center for Severe Weather Research & NEXRAD & Next Generation Weather Radar \\
\hline CSU & Colorado State University & NPS & Naval Postgraduate School \\
\hline DIAL & Differential absorption lidar & NSF & National Science Foundation \\
\hline \multirow[t]{2}{*}{ DOE ARM } & Department of Energy Atmospheric & NSSL & National Severe Storms Laboratory \\
\hline & Radiation Measurement & NWP & Numerical weather prediction \\
\hline DOW & Doppler on Wheels (radar) & $\mathrm{OU}$ & University of Oklahoma \\
\hline $\mathrm{FP}$ & Fixed PISA & PECAN & Plains Elevated Convection at Night \\
\hline GIS & Geographical information system & PHI & Probabilistic hazard information \\
\hline GPS & Global positioning system & PISA & PECAN Integrated Sounding Array \\
\hline \multirow[t]{2}{*}{ HRRR } & High-Resolution Rapid Refresh & PV & Potential vorticity \\
\hline & model & PWV & Precipitable water vapor \\
\hline IHOP & International Water Vapor Project & QPF & Quantitative precipitation forecast \\
\hline IOP & Intensive observation period & RaXPol & Rapid X-band Polarimetric (radar) \\
\hline ISS & Integrated sounding system & RHI & Range-height indicator \\
\hline \multirow[t]{2}{*}{ LASE } & Lidar Atmospheric Sensing Experi- & SBL & Stable boundary layer \\
\hline & ment & SMART-R & Shared Mobile Atmospheric Re- \\
\hline LES & Large-eddy simulation & & search and Teaching Radar \\
\hline LLJ & Low-level jet & SPARC & Space Science and Engineering \\
\hline LSR & Lidar scattering ratio & & Center (SSEC) Portable Atmospheric \\
\hline \multirow[t]{2}{*}{ MAP } & Multi-scale data Assimilation and & & Research Center \\
\hline & Predictability & SPC & Storm Prediction Center \\
\hline MAX & Mobile UAH X-band radar & S-Pol & S-band Polarimetric (radar) \\
\hline MCS & Mesoscale convective system & TWOLF & Truck-Mounted Wind Observing \\
\hline $\mathrm{MCV}$ & Mesoscale convective vortex & & Lidar Facility \\
\hline MIPS & Mobile Integrated Profiling System & UAH & University of Alabama in Huntsville \\
\hline MISS & Mobile Integrated Sounding System & UFOs & "Unofficial” field operations \\
\hline \multirow[t]{2}{*}{ MG } & Mobile GPS Advanced Upper-Air & UWKA & University of Wyoming King Air \\
\hline & Sounding system (GAUS) & WCL & Wyoming Cloud Lidar \\
\hline MM & Mobile mesonet & WP & Radar wind profiler \\
\hline MP & Mobile PISA & WRF & Weather Research and Forecasting \\
\hline MPAS & Model for Prediction Across Scales & & Model \\
\hline
\end{tabular}
model

\section{REFERENCES}

Arritt, R. W., T. D. Rink, M. Segal, D. P. Todey, C. A. Clark, M. J. Mitchell, and K. M. Labas, 1997: The Great Plains low-level jet during the warm season of 1993. Mon. Wea. Rev., 125, 2176-2192, doi:10.1175/1520 -0493(1997)125<2176:TGPLLJ>2.0.CO;2.

Augustine, J. A., and F. Caracena, 1994: Lower-tropospheric precursors to nocturnal MCS development 
Carbone, R. E., J. D. Tuttle, D. A. Ahijevych, and S. B. Trier, 2002: Inferences of predictability associated with warm season precipitation episodes. J. Atmos. Sci., 59, 2033-2056, doi:10.1175/1520 -0469(2002)059<2033:IOPAWW>2.0.CO;2.

Clark, A. J., W. A. Gallus, and T. C. Chen, 2007: Comparison of the diurnal precipitation cycle in convection-resolving and non-convection-resolving mesoscale models. Mon. Wea. Rev., 135, 3456-3473, doi:10.1175/MWR3467.1.

Coleman, T. A., and K. R. Knupp, 2011: Radiometer and profiler analysis of the effects of a bore and a solitary wave on the stability of the nocturnal boundary layer. Mon. Wea. Rev., 139, 211-223, doi:10.1175/2010MWR3376.1.

Colman, B. R., 1990: Thunderstorms above frontal surfaces in environments without positive CAPE. Part I: A climatology. Mon. Wea. Rev., 118, 1103-1122, doi:10.1175/1520-0493(1990)118<1103:TAFSIE $>2$ $.0 . \mathrm{CO} ; 2$.

Coniglio, M. C., J. Y. Hwang, and D. J. Stensrud, 2010: Environmental factors in the upscale growth and longevity of MCSs derived from Rapid Update Cycle analyses. Mon. Wea. Rev., 138, 3514-3539, doi:10.1175/2010MWR3233.1.

Crook, N. A., and M. W. Moncrieff, 1988: The effect of large-scale convergence on the generation and maintenance of deep moist convection. $J$. Atmos. Sci., 45, 3606-3624, doi:10.1175/1520-0469 (1988)045<3606:TEOLSC>2.0.CO;2.

- , R. Carbone, M. W. Moncrieff, and J. W. Conway, 1990: The generation and propagation of a nocturnal squall line. Part II: Numerical simulation. Mon. Wea. Rev., 118, 50-65, doi:10.1175/1520 -0493(1990)118<0050:TGAPOA>2.0.CO;2.

Davis, C. A., K. W. Manning, R. E. Carbone, S. B. Trier, and J. D. Tuttle, 2003: Coherence of warmseason continental rainfall in numerical weather prediction models. Mon. Wea. Rev., 131, 2667-2679, doi:10.1175/1520-0493(2003)131<2667:COWCRI $>2.0 . \mathrm{CO} ; 2$.

— - and Coauthors, 2004: The Bow Echo and MCV Experiment: Observations and opportunities. Bull. Amer. Meteor. Soc., 85, 1075-1093, doi:10.1175 /BAMS-85-8-1075.

Fovell, R. G., G. L. Mullendore, and S.-H. Kim, 2006: Discrete propagation in numerically simulated nocturnal squall lines. Mon. Wea. Rev., 134, 3735-3752, doi:10.1175/MWR3268.1.

French, J., and M. D. Parker, 2010: The response of simulated nocturnal convective systems to a developing low-level jet. J. Atmos. Sci., 67, 3384-3408, doi:10.1175/2010JAS3329.1.
Fritsch, J. M., and G. S. Forbes, 2001: Mesoscale convective systems. Severe Convective Storms, Meteor. Monogr., No. 50, Amer. Meteor. Soc., 323-358, doi:10.1175/0065-9401-28.50.323.

- , and R. E. Carbone, 2004: Improving quantitative precipitation forecasts in the warm season: A USWRP research and development strategy. Bull. Amer. Meteor. Soc., 85, 955-965, doi:10.1175/BAMS -85-7-955.

Haertel, P. T., R. H. Johnson, and S. N. Tulich, 2001: Some simple simulations of thunderstorm outflows. J. Atmos. Sci., 58, 504-516, doi:10.1175/1520 $-0469(2001) 058<0504:$ SSSOTO $>2.0$.CO;2.

Haghi, K. R., D. Parsons, and B. Blake, 2015: Forecasting bores during PECAN 2015: A case study. 16th Conf. on Mesoscale Processes, Boston, MA, Amer. Meteor. Soc., 13.5. [Available online at https://ams.confex .com/ams/16Meso/webprogram/Paper274581.html.]

Heideman, K. F., and J. M. Fritsch, 1988: Forcing mechanisms and other characteristics of significant summertime precipitation. Wea. Forecasting, 3, 115-130, doi:10.1175/1520-0434(1988)003<0115:FM $\mathrm{AOCO}>2.0 . \mathrm{CO} ; 2$.

Jirak, I. L., and W. R. Cotton, 2007: Observational analysis of the predictability of mesoscale convective systems. Wea. Forecasting, 22, 813-838, doi:10.1175 /WAF1012.1.

Johnson, A., X. Wang, and S. Degelia, 2015: Real-time multi-scale GSI-based ensemble data assimilation and forecasting in support of the 2015 PECAN field campaign. 37th Conf. on Radar Meteorology, Norman, OK, Amer. Meteor. Soc., 211. [Available online at https://ams.confex.com/ams/37RADAR /webprogram/Paper275889.html.]

Jorgensen, D. P., T. R. Shepherd, and A. S. Goldstein, 2000: A dual-pulse repetition frequency scheme for mitigating velocity ambiguities of the NOAA P-3 airborne Doppler radar. J. Atmos. Oceanic Technol., 17, 585-594, doi:10.1175/1520-0426(2000)017<0585:AD PRFS $>2.0 . \mathrm{CO} ; 2$.

Kain, J. S., and Coauthors, 2013: A feasibility study for probabilistic convection initiation forecasts based on explicit numerical guidance. Bull. Amer. Meteor. Soc., 94, 1213-1225, doi:10.1175/BAMS-D-11-00264.1.

Karstens, C. D., and Coauthors, 2015: Evaluation of a probabilistic forecasting methodology for severe convective weather in the 2014 Hazardous Weather Testbed. Wea. Forecasting, 30, 1551-1570, doi:10.1175 /WAF-D-14-00163.1.

Kincer, J. B., 1916: Daytime and nighttime precipitation and their economic significance. Mon. Wea. Rev., 44, 628-633, doi:10.1175/1520-0493(1916)44<628:DANP $\mathrm{AT}>2.0 . \mathrm{CO} ; 2$. 
Knupp, K., 2006: Observational analysis of a gust front to bore to solitary wave transition within an evolving nocturnal boundary layer. J. Atmos. Sci., 63, 2016-2035, doi:10.1175/JAS3731.1.

Koch, S. E., W. Feltz, F. Fabry, M. Pagowski, B. Geerts, D. O. Miller, and J. W. Wilson, 2008: Turbulent mixing processes in atmospheric bores and solitary waves deduced from profiling systems and numerical simulation. Mon. Wea. Rev., 136, 1373-1400, doi:10.1175/2007MWR2252.1.

Laing, A. G., and J. M. Fritsch, 2000: The large-scale environments of the global populations of mesoscale convective complexes. Mon. Wea. Rev., 128, 27562776, doi:10.1175/1520-0493(2000)128<2756:TLSE OT>2.0.CO;2.

Li, Y., and R. B. Smith, 2010: The detection and significance of diurnal pressure and potential vorticity anomalies east of the Rockies. J. Atmos. Sci., 67, 2734-2751, doi:10.1175/2010JAS3423.1.

Maddox, R. A., 1980: Mesoscale convective complexes. Bull. Amer. Meteor. Soc., 61, 1374-1387, doi:10.1175/1520-0477(1980)061<1374:MCC >2.0.CO;2.

—, C. F. Chappell, and L. R. Hoxit, 1979: Synoptic and meso-a scale aspects of flash flood events. Bull. Amer. Meteor. Soc., 60, 115-123, doi:10.1175/1520 -0477-60.2.115.

Mapes, B. E., 1993: Gregarious tropical convection. J. Atmos. Sci., 50, 2026-2037, doi:10.1175/1520 -0469(1993)050<2026:GTC>2.0.CO;2.

—, T. T. Warner, and M. Xu, 2003: Diurnal patterns of rainfall in northwestern South America. Part III: Diurnal gravity waves and nocturnal convection offshore. Mon. Wea. Rev., 131, 830-844, doi:10.1175/1520 -0493(2003)131<0830:DPORIN>2.0.CO;2.

Marsham, J. H., S. B. Trier, T. M. Weckwerth, and J. W. Wilson, 2011: Observations of elevated convection initiation leading to a surface-based squall-line during 13 June IHOP_2002. Mon. Wea. Rev., 139, 247-271, doi:10.1175/2010MWR3422.1.

McFarquhar, G. M., M. S. Timlin, R. M. Rauber, B. F. Jewett, J. A. Grim, and D. P. Jorgensen, 2007: Vertical variability of cloud hydrometeors in the stratiform region of mesoscale convective systems and bow echoes. Mon. Wea. Rev., 135, 3405-3428, doi:10.1175 /MWR3444.1.

Parker, M. D., 2008: Response of simulated squall lines to low-level cooling. J. Atmos. Sci., 65, 1323-1341, doi:10.1175/2007JAS2507.1.

Peters, J. M., and R. S. Schumacher, 2015: Mechanisms for organization and echo training in a flashflood-producing mesoscale convective system. Mon. Wea. Rev., 143, 1058-1085, doi:10.1175/MWR -D-14-00070.1.
Pinto, J. O., J. A. Grim, and M. Steiner, 2015: Assessment of the High-Resolution Rapid Refresh Model's ability to predict large convective storms using objectbased verification. Wea. Forecasting, 30, 892-913, doi:10.1175/WAF-D-14-00118.1.

Pitchford, K. L., and J. London, 1962: The low-level jet as related to nocturnal thunderstorms over Midwest United States. J. Appl. Meteor., 1, 43-47, doi:10.1175/1520-0450(1962)001<0043:TLLJAR $>2.0 . \mathrm{CO} ; 2$.

$\mathrm{Pu}, \mathrm{B}$., and R. E. Dickinson, 2014: Diurnal spatial variability of Great Plains summer precipitation related to the dynamics of the low-level jet. J. Atmos. Sci., 71, 1807-1817, doi:10.1175/JAS-D-13-0243.1.

Raymond, D. J., and R. Rotunno, 1989: Response of a stably stratified flow to cooling. J. Atmos. Sci., 46, 28302837, doi:10.1175/1520-0469(1989)046<2830:ROASS $\mathrm{F}>2.0 . \mathrm{CO} ; 2$.

Rodwell, M. J., and Coauthors, 2013: Characteristics of occasional poor medium-range weather forecasts for Europe. Bull. Amer. Meteor. Soc., 94, 1393-1405, doi:10.1175/BAMS-D-12-00099.1.

Rottman, J. W., and J. E. Simpson, 1989: The formation of internal bores in the atmosphere: A laboratory model. Quart. J. Roy. Meteor. Soc., 115, 941-963, doi:10.1002/qj.49711548809.

Rotunno, R., J. B. Klemp, and M. L. Weisman, 1988: A theory for strong, long-lived squall lines. J. Atmos. Sci., 45, 463-485, doi:10.1175/1520-0469(1988)045 $<0463$ :ATFSLL $>2.0$.CO;2.

Schmidt, J. M., and W. R. Cotton, 1990: Interactions between upper and lower tropospheric gravity waves on squall line structure and maintenance. $J$. Atmos. Sci., 47, 1205-1222, doi:10.1175/1520-0469 (1990)047<1205:IBUALT>2.0.CO;2.

Schumacher, R. S., 2009: Mechanisms for quasi-stationary behavior in simulated heavy-rain-producing convective systems. J. Atmos. Sci., 66, 1543-1568, doi:10.1175/2008JAS2856.1.

— - and R. H. Johnson, 2009: Quasi-stationary, extreme-rain-producing convective systems associated with midlevel cyclonic circulations. Wea. Forecasting, 24, 555-574, doi:10.1175/2008WAF2222173.1.

Smith, A. M., G. M. McFarquhar, R. M. Rauber, J. A. Grim, M. S. Timlin, B. F. Jewett, and D. P. Jorgensen, 2009: Microphysical and thermodynamic structure and evolution of the trailing stratiform regions of mesoscale convective systems during BAMEX. Part I: Observations. Mon. Wea. Rev., 137, 1165-1185, doi:10.1175/2008MWR2504.1.

Stensrud, D. J., 1996: Effects of persistent, midlatitude mesoscale regions of convection on the largescale environment during the warm season. $J$. 
Atmos. Sci., 53, 3503-3527, doi:10.1175/1520-0469 (1996)053<3503:EOPMMR>2.0.CO;2.

Surcel, M., M. Berenguer, and I. Zawadzki, 2010: The diurnal cycle of precipitation from continental radar mosaics and numerical weather prediction models. Part I: Methodology and seasonal comparison. Mon. Wea. Rev., 138, 3084-3106, doi:10.1175/2010MWR3125.1.

Trenberth, K. E., A. Dai, R. M. Rasmussen, and D. B. Parsons, 2003: The changing character of precipitation. Bull. Amer. Meteor. Soc., 84, 1205-1217, doi:10.1175/BAMS-84-9-1205.

Trier, S. B., C. A. Davis, and D. A. Ahijevych, 2010: Environmental controls on the simulated diurnal cycle of warm-season precipitation in the continental United States. J. Atmos. Sci., 67, 1066-1090, doi:10.1175/2009JAS3247.1.

Tripoli, G. J., and W. R. Cotton, 1989a: Numerical study of an observed orogenic mesoscale convective system. Part I: Simulated genesis and comparison with observations. Mon. Wea. Rev., 117, 273-304, doi:10.1175/1520-0493(1989)117<0273:NSOAOO $>2.0 . \mathrm{CO} ; 2$.

— , and _ 1989b: Numerical study of an observed orogenic mesoscale convective system. Part II: Simulated genesis and comparison with observations. Mon. Wea. Rev., 117, 273-304, doi:10.1175/1520 -0493(1989)117<0273:NSOAOO>2.0.CO;2.

Tuttle, J. D., and C. A. Davis, 2006: Corridors of warm season precipitation in the central United States. Mon. Wea. Rev., 134, 2297-2317, doi:10.1175/MWR3188.1.

Wallace, J. M., 1975: Diurnal variations in precipitation and thunderstorm frequency over the conterminous United States. Mon. Wea. Rev., 103, 406-419, doi:10.1175/1520-0493(1975)103<0406:DVIPAT >2 $.0 . \mathrm{CO} ; 2$.

Wang, Z., and Coauthors, 2011: Observations of boundary layer water vapor and aerosol structures with a compact airborne Raman lidar. Fifth Symp. on Lidar Atmospheric Applications, Seattle, WA, Amer. Meteor. Soc., 3.6. [Available online at https://ams.confex.com /ams/91Annual/webprogram/Paper187254.html.]

Weckwerth, and Coauthors, 2004: An overview of the International $\mathrm{H}_{2} \mathrm{O}$ Project (IHOP_2002) and some preliminary highlights. Bull. Amer. Meteor. Soc., 85, 253-277, doi:10.1175/BAMS-85-2-253.

Weisman, M. L., and R. Rotunno, 2004: "A theory for strong long-lived squall lines" revisited. J. Atmos. Sci., 61, 361-382, doi:10.1175/1520-0469(2004)061 $<0361$ :ATFSLS $>2.0 . \mathrm{CO} ; 2$.

- C. Davis, W. Wang, K. W. Manning, and J. B. Klemp, 2008: Experiences with 0-36-h explicit convective forecasts with the WRF-ARW model. Wea. Forecasting, 23, 407-437, doi:10.1175/2007WAF2007005.1.

— , and Coauthors, 2015: The Mesoscale Predictability Experiment (MPEX). Bull. Amer. Meteor. Soc., 96, 2127-2149, doi:10.1175/BAMS-D-13-00281.1.

Whiteman, D. N., and Coauthors, 2006: Raman Lidar Measurements during the International $\mathrm{H} 2 \mathrm{O}$ Project. Part II: Case studies. J. Atmos. Oceanic Technol., 23, 170-183, doi:10.1175/JTECH1839.1.

Wilson, J. W., and W. E. Schreiber, 1986: Initiation of convective storms at radar-observed boundary-layer convergence lines. Mon. Wea. Rev., 114, 2516-2536, doi:10.1175/1520-0493(1986)114<2516:IOCSAR $>2.0 . \mathrm{CO} ; 2$.

— , and R. D. Roberts, 2006: Summary of convective storm initiation and evolution during IHOP: Observational and modeling perspective. Mon. Wea. Rev., 134, 23-47, doi:10.1175/MWR3069.1.

Ziegler, C. L., 2013: A diabatic Lagrangian technique for the analysis of convective storms. Part II: Application to a radar-observed storm. J. Atmos. Oceanic Technol., 30, 2266-2280, doi:10.1175/JTECH -D-13-00036.1. 